\title{
BIOCHAR AS A TOOL TO REDUCE THE AGRICULTURAL GREENHOUSE- GAS BURDEN - KNOWNS, UNKNOWNS AND FUTURE RESEARCH NEEDS
}

\author{
Claudia KAMMANN ${ }^{a}$, Jim IPPOLITO ${ }^{\mathrm{b}}$, Nikolas HAGEMANN ${ }^{c}$, Nils BORCHARD ${ }^{\mathrm{d}}$, Maria Luz CAYUELA ${ }^{\mathrm{e}}$, \\ José M. ESTAVILLO ${ }^{\mathrm{f}}$, Teresa FUERTES-MENDIZABAL ${ }^{\mathrm{f}}$, Simon JEFFERYg, Jürgen KERN ${ }^{\mathrm{h}}$, Jeff NOVAK ${ }^{\mathrm{i}}$, \\ Daniel RASSE', Sanna SAARNIO ${ }^{\mathrm{k}}$, Hans-Peter SCHMIDT ${ }^{1}$, Kurt SPOKAS ${ }^{\mathrm{m}}$, Nicole WRAGE-MÖNNIG ${ }^{\mathrm{n}}$ \\ ${ }^{a}$ Department of Soil Science and Plant Nutrition, WG Climate Change Research for Special Crops, \\ Hochschule Geisenheim University, Von-Lade Str. 1, 65366 Geisenheim, Germany \\ ${ }^{b}$ Department of Soil and Crop Sciences, Colorado State University, Fort Collins, CO 80523-1170, USA \\ ${ }^{c}$ Geomicrobiology, Center for Applied Geosciences, University Tübingen, Hölderlinstr. 12, 72074 Tübingen, Germany \\ ${ }^{d}$ Center for International Forestry Research, Jalan CIFOR, Situ Gede, Sindang Barang, Bogor 16115, Indonesia \\ 'Department of Soil and Water Conservation and Waste Management, CEBAS-CSIC, \\ Campus Universitario de Espinardo, 30100 Murcia, Spain \\ ${ }^{f}$ Department of Plant Biology and Ecology, University of the Basque Country (UPV/EHU), \\ Apdo. 644, E-48080 Bilbao, Spain \\ ${ }^{8}$ Crop and Environment Sciences Department, Harper Adams University, Newport, Shropshire, \\ TF10 8NB, United Kingdom \\ ${ }^{h}$ Department of Bioengineering, Leibniz Institute for Agricultural Engineering and Bioeconomy, \\ Max-Eyth-Allee 100, 14469 Potsdam, Germany \\ ${ }^{i}$ United States Department of Agriculture, Agricultural Research Service (USDA-ARS),
} Water and Plant Conservation Research, 2611 W Lucas street, Florence, South Carolina 295011242, USA

${ }^{j}$ Department of Soil Quality and Climate Change, Norwegian Institute of Bioeconomy Research, Høgskoleveien 7, 1430 Aas, Norway

${ }^{k}$ Department of Environmental and Biological Sciences, University of Eastern Finland, P.O. Box 111, 80101 Joensuu, Finland

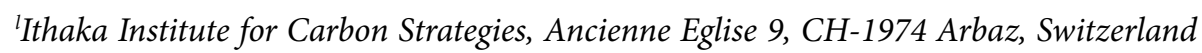

${ }^{m}$ United States Department of Agriculture, Agricultural Research Service (USDA-ARS) and University of Minnesota, Department of Soil, Water, and Climate, 1529 Gortner Ave., St. Paul, MN 55108, USA ${ }^{n}$ Grassland and Fodder Sciences, Faculty of Agriculture and the Environment, University of Rostock, Justus-von-Liebig-Weg 6, 18051 Rostock, Germany

Submitted 7 Jan. 2017; accepted 11 Apr. 2017

\begin{abstract}
Agriculture and land use change has significantly increased atmospheric emissions of the non- $\mathrm{CO}_{2}$ greenhouse gases $(\mathrm{GHG})$ nitrous oxide $\left(\mathrm{N}_{2} \mathrm{O}\right)$ and methane $\left(\mathrm{CH}_{4}\right)$. Since human nutritional and bioenergy needs continue to increase, at a shrinking global land area for production, novel land management strategies are required that reduce the GHG footprint per unit of yield. Here we review the potential of biochar to reduce $\mathrm{N}_{2} \mathrm{O}$ and $\mathrm{CH}_{4}$ emissions from agricultural practices including potential mechanisms behind observed effects. Furthermore, we investigate alternative uses of biochar in agricultural land management that may significantly reduce the GHG-emissions-per-unit-ofproduct footprint, such as (i) pyrolysis of manures as hygienic alternative to direct soil application, (ii) using biochar
\end{abstract}


as fertilizer carrier matrix for underfoot fertilization, biochar use (iii) as composting additive or (iv) as feed additive in animal husbandry or for manure treatment. We conclude that the largest future research needs lay in conducting lifecycle GHG assessments when using biochar as an on-farm management tool for nutrient-rich biomass waste streams.

Keywords: biochar, greenhouse gases $(\mathrm{GHG})$, nitrous oxide $\left(\mathrm{N}_{2} \mathrm{O}\right)$, methane $\left(\mathrm{CH}_{4}\right)$, soil aeration, nitrate, soil $\mathrm{N}$ transformations, GHG intensity.

\section{Introduction: Human impact on global $\mathrm{N}_{2} \mathrm{O}$ and $\mathrm{CH}_{4}$ budgets and atmospheric concentrations}

Human population now approaches 7.5 billion people on earth. The land area that serves human nutrition and bioenergy demands is not only limited, but declining due to soil degradation in various forms (Lal 2014; Konuma 2016; FAO 2015). The dawning perception that "fertile soils" are a finite global resource is stressed by recent land grabbing practices where wealthier countries with large populations and/or a lack of soil resources buy arable land in poorer countries. This has mostly occurred in Africa (Rulli et al. 2013), causing land use change to increase crop productivity, likely with consequences in terms of increasing GHG production. In fact, excessive human land use change over the past decades has contributed to the rapid, on-going increase in the atmospheric concentration of non- $\mathrm{CO}_{2}$ greenhouse gases nitrous oxide $\left(\mathrm{N}_{2} \mathrm{O}\right)$ and methane $\left(\mathrm{CH}_{4}\right)$ from preindustrial levels of 270-280 ppbv to $324 \mathrm{ppbv}$ $\left(\mathrm{N}_{2} \mathrm{O}\right)$ and from $~ 700$ ppbv to $1834 \mathrm{ppbv}\left(\mathrm{CH}_{4}\right)$ (Myhre et al. 2013; Saunois et al. 2016).

The steep increase in atmospheric $\mathrm{N}_{2} \mathrm{O}$ concentrations dominantly since the $1950^{\mathrm{s}}$ is clearly the result of an increasing use of the Haber-Bosch process to generate reactive $\mathrm{N}$ forms from atmospheric $\mathrm{N}$, plus the higher proportion of legumes on farmland compared to natural ecosystems; many important crop or fodder plants are $\mathrm{N}_{2}-$ fixing legumes (e.g. soy, pea, lentils, beans, groundnuts, clover). Global reactive-N use is now annually more than double the amount introduced by natural processes (Galloway et al. 2008); with increasing $\mathrm{N}$ fertilizer use comes the increasing likelihood of $\mathrm{N}_{2} \mathrm{O}$ formation and atmospheric accumulation. Thus, as stated by Ravishankara et al. (2009), as the impact of fluorinated halocarbons decreases, $\mathrm{N}_{2} \mathrm{O}$ will likely become the dominant $\mathrm{O}_{3}$-depleting substance within the agricultural sector over the course of the $21^{\text {st }}$ century.

Methane $\left(\mathrm{CH}_{4}\right)$ emissions have also increased, by $150 \%$ since 1750 (Myhre et al. 2013) to $1834 \mathrm{ppb}$ in 2015 (Dlugokencky et al. 1994; Saunois et al. 2016). Human activities directly and indirectly contribute to the increased atmospheric $\mathrm{CH}_{4}$ concentration by several pathways such as (i) expanding rice agriculture, ruminant animal husbandry and landfilling with unmanaged $\mathrm{CH}_{4}$ emissions, (ii) thawing permafrost areas and thermocast lakes (Koven et al. 2011; Walter et al. 2006) and warminginduced changes in plant community composition e.g. expanding aerenchymal plant cover (Christensen et al. 2004), and (iii) "automatic" feedback effects such as rising
$\mathrm{CH}_{4}$ production under elevated, rising atmospheric $\mathrm{CO}_{2}$ concentrations from wetlands and agricultural lands due to higher net biomass production as labile substrates for methanogenesis (Van Groenigen et al. 2011).

To our knowledge, the last assessment of the human impact of land-use changes and fertilizer use on global $\mathrm{CH}_{4}$ consumption was made 20 years ago (Ojima et al. 1993). The authors estimated that human activities have already reduced the global net $\mathrm{CH}_{4}$ sink capacity by $30 \%$. Hypotheses for explaining the reduction encompass human impact on (i) soil moisture changes, (ii) reduced soil aeration via compaction / increased bulk density (both impact gas diffusivity and hence $\mathrm{CH}_{4}$ and $\mathrm{O}_{2}$ supply, (Castro et al. 1994; Hiltbrunner et al. 2012), and (iii) inhibition by $\mathrm{NH}_{4}{ }^{+}(\mathrm{N}$ fertilization or reduced nitrification in acidic soils (Schnell, King 1995; Steudler et al. 1989). Also, (iv) shifts in the microbial community composition are hypothesized, but without conclusive evidence (Gulledge et al. 1997).

Over the last decades, the rising use of mineral $\mathrm{N}$ fertilizer (Galloway et al. 2008), soil degradation and forest clear-cutting, and a rising frequency of weather extremes (Hansen, Sato 2016) creating "too wet" or "too dry" soil conditions (Dijkstra et al. 2011) will likely further reduce the global methanotrophic $\mathrm{CH}_{4}$ sink, and increase $\mathrm{CH}_{4}$ and $\mathrm{N}_{2} \mathrm{O}$ emissions. Therefore, any positive contribution that science and material use may provide agricultural soils for reducing $\mathrm{N}_{2} \mathrm{O}$ emissions per unit yield, and in reducing either the $\mathrm{CH}_{4}$ production and surface emissions from soils or ruminant guts (see sections 3 and 4), or by strengthening the soil $\mathrm{CH}_{4}$ oxidation capacity (section 3.2) and its biofilter function (section 3.1), needs to be explored. Agricultural practices that utilize biochar for meeting these needs appears promising, and should be explored and developed to help lower the greenhouse gas (GHG) footprint per unit yield or bioenergy produced (also termed GHG intensity) (Wollenberg et al. 2016).

A reduction of $\mathrm{N}_{2} \mathrm{O}$ and $\mathrm{CH}_{4}$ within agroecosystems can be achieved by either increasing the per-hectare yield at unchanged GHG emission rates, by lowering the perhectare $\mathrm{N}_{2} \mathrm{O}$ and/or $\mathrm{CH}_{4}$ emissions/increasing $\mathrm{CH}_{4}$ uptake, or ideally by both. Currently literature suggests that biochar may play a role in reducing both of these GHGs; biochar can affect GHG emissions directly following its application to soils, and indirectly by adding carbonized instead of non-carbonised residue or manures which usually have higher emissions following application. Thus, the aim of this paper is to explore our current understanding 
and knowledge gaps of biochar use as a tool to reduce $\mathrm{N}_{2} \mathrm{O}$ and $\mathrm{CH}_{4}$ emissions from agricultural land use. To this end, the biogeochemical mechanisms of formation and consumption of $\mathrm{N}_{2} \mathrm{O}$ and $\mathrm{CH}_{4}$ in soils and their emission to the atmosphere are presented and discussed. The topic of build-up of the soil organic carbon stocks by biochar amendment, or by reduced soil organic carbon decomposition (negative priming) is not explored here, only some rough assessments are made to illustrate potentials (e.g. for using biochar as animal feed additive).

\section{Effects of biochar application to soils on $\mathrm{N}_{2} \mathrm{O}$ emissions}

\subsection{Mechanisms of $\mathrm{N}_{2} \mathrm{O}$ formation in soils and release to the atmosphere}

Soils are a prominent source of $\mathrm{N}_{2} \mathrm{O}$ emissions, especially when fertilised with organic or mineral $\mathrm{N}$ fertilisers. A wide range of microbial and chemical processes and pathways are responsible for these emissions (see Fig. 1), with knowledge on these pathways continuously improving. The classical view was that bacterial denitrification, the reduction of nitrate and nitrite in several steps to $\mathrm{N}_{2}$, is the main source of $\mathrm{N}_{2} \mathrm{O}$ from most soils, especially at intermediate water contents (Bateman, Baggs 2005). Various bacteria that are phylogenetically unrelated are capable of denitrification, with many not having the full set of enzymes for the complete pathway (Zumft 1997). This leads to the escape of intermediates, including $\mathrm{N}_{2} \mathrm{O}$. Under certain circumstances such as low $\mathrm{pH}$ and high $\mathrm{NO}_{3} /$ $\mathrm{C}_{\text {org }}$ ratios, the production of $\mathrm{N}_{2} \mathrm{O}$ is favoured compared to the final production of $\mathrm{N}_{2}$. The reduction of $\mathrm{N}_{2} \mathrm{O}$ to $\mathrm{N}_{2}$ is performed by the enzyme nitrous oxide reductase, which is encoded by the nosZ gene in denitrifying bacteria. In a laboratory study, lower $\mathrm{N}_{2} \mathrm{O}$ emissions were inversely correlated to the nosZ gene expression (Harter et al. 2014).
Meanwhile, we know that bacterial nitrifiers may dominate $\mathrm{N}_{2} \mathrm{O}$ emission from some soils, e.g. by the pathway nitrifier denitrification (Kool et al. 2011a). Bacterial nitrifiers use ammonia as a substrate and reduce intermediately produced nitrite in a comparable way as in denitrification. Nitrifiers have been found to be also able to use nitrite provided exogenously in incubation studies under aerobic conditions (Shaw et al. 2006). Fungi may play a dominant role for $\mathrm{N}_{2} \mathrm{O}$ production from soils, either by codenitrification or by fungal denitrification (Laughlin, Stevens 2002; Rohe et al. 2014). The role of archaea for $\mathrm{N}_{2} \mathrm{O}$ production from soils is still unknown, but there is evidence of potentially significant archaeal contributions (Jung et al. 2014), although the responsible pathways are yet unresolved (Jung et al. 2014; Stieglmeier et al. 2014).

As these processes may take place simultaneously in different soil microsites, it is not straightforward to distinguish among them. Several methods have recently been developed that try to unravel the sources of $\mathrm{N}_{2} \mathrm{O}$, including stable isotopes (Sutka et al. 2006; Kool et al. 2011b; Rohe et al. 2014; Lewicka-Szczebak et al. 2016) and molecular or modelling approaches (Rütting, Müller 2007; Kozlowski et al. 2014; Perez-Garcia et al. 2014; Snider et al. 2015). So far, no single method has offered a complete picture of the diverse $\mathrm{N}_{2} \mathrm{O}$ producing pathways and a combination of methods seems most promising.

\subsection{Impact of biochar on soil $\mathrm{N}_{2} \mathrm{O}$ emissions: frequent observations and assumed mechanisms}

One of the first biochar experiments reporting reduced $\mathrm{N}_{2} \mathrm{O}$ emissions was presented in the $3^{\text {rd }}$ USDA Symposium on greenhouse gases and carbon sequestration in agriculture and forestry (Rondon et al. 2005). A significant decrease in $\mathrm{N}_{2} \mathrm{O}$ emissions was observed in pots planted with soybean and grass in a greenhouse experiment. However,

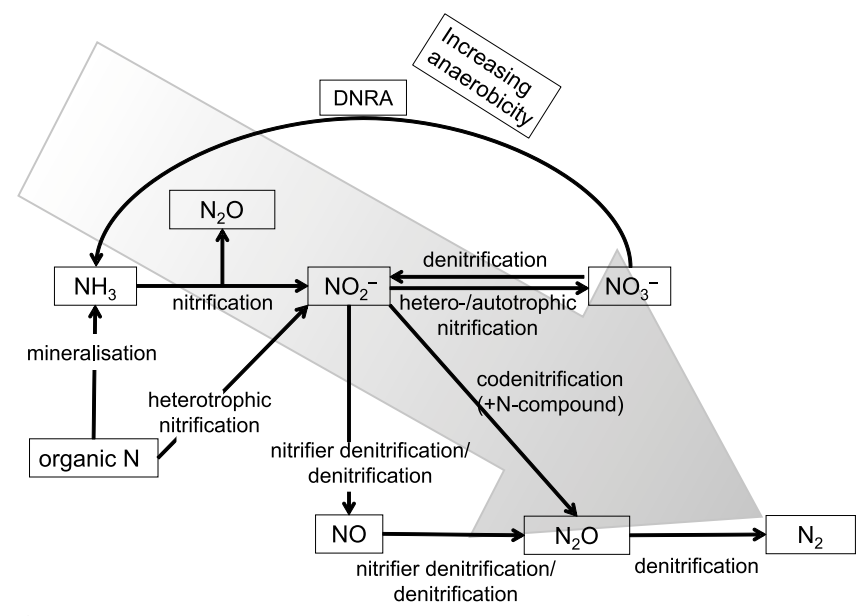

a)

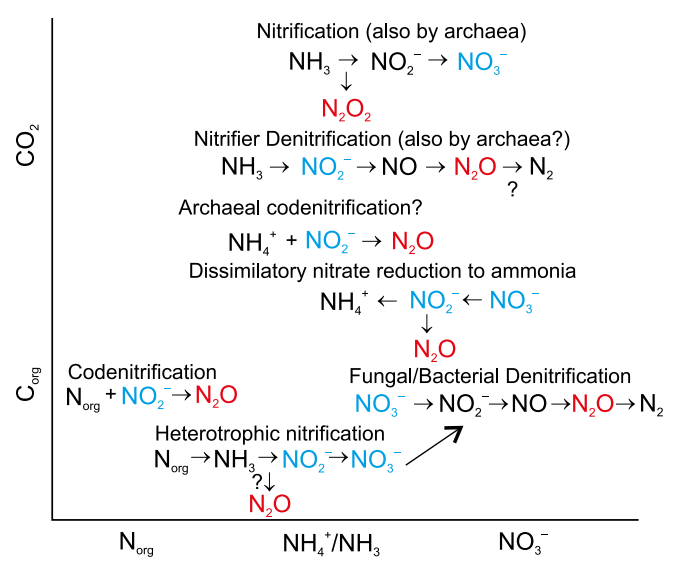

b)

Fig. 1. a) Processes and b) pathways of $\mathrm{N}$ conversions associated with $\mathrm{N}_{2} \mathrm{O}$ emissions in soils in relation to $\mathrm{N}$ transformations (A) and $\mathrm{N}$ and C substrates (B). (Figure credit: N. Wrage-Mönnig) 
this finding went unnoticed for several years and only after the pioneering studies by Yanai et al. (2007), Spokas et al. (2009) and van Zwieten et al. (2009), the number of publications on this topic started to rise. Hence, a new field of research was established, exploring a potential win-win situation: biochar not only sequestered carbon but also had the potential to decrease non- $\mathrm{CO}_{2}$ GHG emissions.

To date, the hypotheses for biochar's impact in charsoil mixtures on $\mathrm{N}_{2} \mathrm{O}$ emissions has been linked to biochar properties, the soil and the environmental conditions such as temperature and precipitation (Spokas, Reicoscoky 2009; Dicke et al. 2015). Studies have mostly been carried out in the lab using sieved/disturbed soil samples wetted either to the same gravimetric moisture, or to the same water-filled pore space, water holding capacity or water potential. Other investigations in combination with plant growth in the greenhouse or under less controlled conditions in the field have also shown that biochar may affect the soil $\mathrm{N}_{2} \mathrm{O}$ emissions (e.g. Taghizadeh-Toosi et al. 2011; Schimmelpfennig et al. 2014; Kammann et al. 2012; Deng et al. 2015; Hüppi et al. 2015). In the presence of $\mathrm{N}_{2} \mathrm{O}$-producing earthworms (soil fauna interactions), $\mathrm{N}_{2} \mathrm{O}$ emissions were also reduced by biochar application ( $\mathrm{Au}-$ gustenborg et al. 2012; Bamminger et al. 2014). However, in some studies no difference between biochar and control treatments was observed (Scheer et al. 2011; SánchezGarcía et al. 2016) or $\mathrm{N}_{2} \mathrm{O}$ emissions were increased from biochar amended soils (e.g. Spokas, Reicoscoky 2009; Clough et al. 2010; Saarnio et al. 2013; Troy et al. 2013). However, laboratory results cannot be generalised to field expectations. In field trials, often no statistical differences are observed between biochar and control treatments following field application of biochar (Castaldi et al. 2011; Jones et al. 2012; Karhu et al. 2011; Scheer et al. 2011; Schimmelpfennig et al. 2014; Suddick, Six 2013; Dicke et al. 2015). One potential reason for no significant biochar effects on $\mathrm{N}_{2} \mathrm{O}$ emissions may be the application dose, less homogeneous particle distribution and greater soil (and plant) heterogeneity in fields resulting in high variability in $\mathrm{N}_{2} \mathrm{O}$ fluxes (large error bars, e.g. Hüppi et al. 2015).

Nevertheless, overall, meta-analyses confirmed that $\mathrm{N}_{2} \mathrm{O}$ emissions are reduced with biochar application rates of $1-2 \%$ by weight (van Zwieten et al. 2015; Cayuela et al. 2014). In spite of the extensive literature published during the past several years on the topic, knowing if a biochar will be effective in mitigating $\mathrm{N}_{2} \mathrm{O}$ emissions in a certain agricultural field is still highly unpredictable. Thus, most research efforts are now directed towards achieving the largest $\mathrm{N}_{2} \mathrm{O}$ emission reductions (what type of biochar to use in what soils) by analysing the mechanisms involved. Many studies have shown that biochar $\mathrm{N}_{2} \mathrm{O}$ mitigation capacity will depend not only on the characteristics of the biochar, but also on the type of soil and predominant environmental conditions (Cayuela et al. 2013; Malghani et al. 2013; Nelissen et al. 2014). A remarkable finding was that, under identical environmental conditions, the same biochar could increase emissions in one soil and decrease emissions in another (Yoo, Kang 2012; Sánchez-García et al. 2014). This fact seems to be linked to diverse $\mathrm{N}_{2} \mathrm{O}$ formation mechanisms operating in different soils, of which biochar might be affecting differently. In this sense, knowing how biochar interacts with the key microbial pathways regulating $\mathrm{N}_{2} \mathrm{O}$ formation and consumption in soil is crucial for developing and implementing effective mitigation strategies. However, the number of studies looking at specific $\mathrm{N}_{2} \mathrm{O}$ formation pathways is still very limited and the mechanisms mediating $\mathrm{N}_{2} \mathrm{O}$ suppression are still unresolved.

To date, most $\mathrm{N}_{2} \mathrm{O}$-biochar studies selected certain environmental conditions and assumed or speculated the predominant $\mathrm{N}_{2} \mathrm{O}$ formation mechanisms. For instance, studies at high water-filled pore space anticipated that the main $\mathrm{N}_{2} \mathrm{O}$ formation pathway would be heterotrophic denitrification. However, this reasoning has frequently been shown to be incorrect. In complex soil environments, ammonia oxidation and nitrifier denitrification generally coexist with heterotrophic denitrification (Hu et al. 2015) and the proportion of $\mathrm{N}_{2} \mathrm{O}$ produced in each pathway depends on many factors, not just water-filled pore space (Wrage et al. 2001; Butterbach-Bahl et al. 2013). Therefore, studies that really differentiate among $\mathrm{N}_{2} \mathrm{O}$ produced by different sources after addition of biochars are still urgently needed.

\subsubsection{What do we know about the impact of biochar on denitrification $\mathrm{N}_{2} \mathrm{O}$ ?}

Denitrification is classically the most well-known mechanism leading to $\mathrm{N}_{2} \mathrm{O}$ emissions and to date, also the most investigated in biochar studies. Biochar might interact with denitrification in different ways. Biochar might directly stimulate or suppress total denitrification, i.e. the amount of $\mathrm{N}$ that goes to gaseous form $\left(\mathrm{N}_{2}+\mathrm{N}_{2} \mathrm{O}+\mathrm{NO}\right)$. The impact of biochar on total denitrification has been barely studied and the results are inconclusive. For instance, using stable isotope enrichment, Cayuela et al. (2013) analyzed the flux of total $\mathrm{N}$ denitrified $\left(\mathrm{N}_{2}+\mathrm{N}_{2} \mathrm{O}\right)$ at the peak of $\mathrm{N}_{2} \mathrm{O}$ emissions and found that biochar decreased the total denitrificatory $\mathrm{N}$ efflux in 9 out of 15 soils, but significantly increased the flux in two soils. Obia et al. (2015) measured $\mathrm{NO}, \mathrm{N}_{2} \mathrm{O}$ and $\mathrm{N}_{2}$ by high resolution gas kinetics under strictly anaerobic conditions and calculated the maximum induced denitrification rate, which was found to increase with one type of biochar (cacao shell), but not with another biochar (rice husk) in an acidic soil. By using the acetylene inhibition technique, Ameloot et al. (2016) found a general decrease in total denitrified $\mathrm{N}\left(\mathrm{N}_{2}+\mathrm{N}_{2} \mathrm{O}\right)$ with biochar in a neutral soil. Biochar might therefore 
decrease or increase total denitrification depending on the type of soil. More studies are needed to understand the mechanisms behind these observations.

A decrease in total denitrification was initially attributed to improved soil aeration following biochar addition (Zhang et al. 2010), a hypothesis that has been rebutted by Case et al. (2012) who demonstrated that soil aeration played a minimal role in $\mathrm{N}_{2} \mathrm{O}$ mitigation. Furthermore, several studies used adjusted water contents to account for increased water holding capacities that often arise when biochar is mixed into the soil (e.g. light-weight porous biochars in sandy soils), to render simple aeration effects unlikely (e.g. Kammann et al. 2012); still these studies observed significant $\mathrm{N}_{2} \mathrm{O}$ emission reductions. Another hypothesis suggested a general decrease in soil microbial activity as a consequence of toxic compounds present in biochar. For example, phenolic compounds and PAHs have been observed to contribute to the reduction in $\mathrm{N}_{2} \mathrm{O}$ release from agricultural soils (Wang et al. 2013a). However, Alburquerque et al. (2015) demonstrated that this hypothesis was unfounded, since the presence of PAHs at typical biochar concentrations did stimulate, rather than inhibit, $\mathrm{N}_{2} \mathrm{O}$ emissions. Moreover, even if PAH containing biochars would reduce $\mathrm{N}_{2} \mathrm{O}$ emissions, they will definitely never be used in soils under any countries' soil and fertilizer regulations. In addition, numerous studies used clean biochars with hardly detectable traces of even the most abundant $\mathrm{PAH}$ (naphthalene) and these studies still showed reduced $\mathrm{N}_{2} \mathrm{O}$ emissions (study compilations in Cayuela et al. (2014) and van Zwieten et al. (2015)).

Several studies pointed out that microbial or physical or plant immobilization of $\mathrm{NO}_{3}^{-}$in soil following biochar addition could significantly contribute to the reduction of soil $\mathrm{N}_{2} \mathrm{O}$ emissions (compilation of $\mathrm{N}_{2} \mathrm{O}$-biochar studies in van Zwieten et al. 2015). This hypothesis is reinforced by recent research showing that biochar is able to capture considerable amounts of nitrate, which is only partly detectable with standard methods and largely protected against leaching (Kammann et al. 2015; Haider et al. 2016). Nitrate capture may physically separate nitrate from denitrifiers and thus reduce nitrate availability.

On the other hand, biochar might interact with the denitrification process by modifying the ratio of denitrification products $\left(\mathrm{N}_{2} \mathrm{O} / \mathrm{N}_{2}\right)$. Thus, biochar may decrease the $\mathrm{N}_{2} \mathrm{O} / \mathrm{N}_{2}$ ratio (Cayuela et al. 2013; Harter et al. 2014; Obia et al. 2015), but many questions arise from this finding. For instance, Obia et al. (2015) related this phenomenon to the alkalinizing effect of biochar in soil. However, the decrease in the $\mathrm{N}_{2} \mathrm{O} / \mathrm{N}_{2}$ ratio has also been found in alkaline soils (Cayuela et al. 2013), where an increase in $\mathrm{pH}$ did not occur after biochar amendment.
Harter et al. (2016) found that biochar addition led to the development of functional traits capable of $\mathrm{N}_{2} \mathrm{O}$ reduction, containing typical and atypical nos $Z$ genes. Following a different line of research, several recent articles highlight the importance of biochar redox properties, which may have a bigger impact on soil biogeochemical processes than previously thought (Prévoteau et al. 2016). In this line, Quin et al. (2015) measured $\mathrm{N}_{2} \mathrm{O}$ reduction by injecting ${ }^{15} \mathrm{~N}-\mathrm{N}_{2} \mathrm{O}$ in sterilized soil columns and demonstrated that biochar took part in abiotic redox reactions reducing $\mathrm{N}_{2} \mathrm{O}$ to dinitrogen $\left(\mathrm{N}_{2}\right)$, in addition to adsorption of $\mathrm{N}_{2} \mathrm{O}$. Despite the current knowledge about the impact of biochar on denitrification, additional studies are highly needed to explore the detailed response mechanisms of denitrifiers to biochar amendment.

\subsubsection{What do we know about the impact of biochar on $\mathrm{N}_{2} \mathrm{O}$ from nitrification and other processes?}

It has been described that gross nitrification rates could be increased after biochar amendment because of higher substrate availability for nitrifying bacteria (Nelissen et al. 2012), and several studies have analysed the impact of biochar on gross and net nitrification (Prommer et al. 2014). There is also a potential that biochar addition may increase nitrification (and with it, $\mathrm{N}_{2} \mathrm{O}$ formation via nitrification pathways; Figure 1 in systems (such as needlerich raw humus soils) due to the sorption of phenolic compounds; the latter can block or reduce nitrification. A significant increase in nitrification was seen in boreal forests after biochar addition (DeLuca et al. 2006; Ball et al. 2010) where sorption of phenols on biochar was responsible for increased nitrification rates. However, only a couple of studies distinguished among $\mathrm{N}_{2} \mathrm{O}$ emissions from nitrification pathways (via ammonia oxidation or nitrifier denitrification) and other sources by using isotopic signatures of $\mathrm{N}_{2} \mathrm{O}$, inhibition techniques or molecular methods. In a laboratory incubation, Sánchez-García et al. (2014) found that the addition of biochar increased $\mathrm{N}_{2} \mathrm{O}$ emissions from a calcareous soil and concluded that the $\mathrm{N}_{2} \mathrm{O}$ formation pathway operating in the soil was nitrification (probably nitrifier-denitrification). In another study, Wells and Baggs (2014) showed that the biochar influence came primarily via ammonia oxidation, not $\mathrm{N}_{2} \mathrm{O}$ reduction or production by denitrifiers, and increased $\mathrm{N}_{2} \mathrm{O}$ emissions by $27 \%$.

Dedicated studies of biochar effects on other soil sources of $\mathrm{N}_{2} \mathrm{O}$ are largely missing. At low soil $\mathrm{pH}$ values, it has been observed that fungi produced $\mathrm{N}_{2} \mathrm{O}$ instead of $\mathrm{N}_{2}$ through codenitrification in presence of other nitrogen compounds, such as azide, salicylhydroxamic acid, nitrite and ammonium (Liiri et al. 2002). Since biochar can contain azide as well as other compounds, biochar 
additions could theoretically enhance these fungal codenitrification processes. There are limited studies examining the functionality of the $\mathrm{N}_{2} \mathrm{O}$ suppression through use of selective microbial inhibitors, and data did support the role of a particular microbial group in the $\mathrm{N}_{2} \mathrm{O}$ suppression (bacteria or fungal, Lin et al. 2014). However, a soil $\mathrm{pH}$ increase caused by biochar addition could also reduce $\mathrm{N}_{2} \mathrm{O}$ production from fungal codenitrification, thus the net outcome is unknown. Microbial community composition will likely play a role: Using an identical biochar in laboratory incubations across a series of 10 different soils, Thomazini et al. (2015) observed a trend for the biochar suppression that could be correlated to the total soil microbial biomass in the original soil. The knowledge of effects of biochar additions on various microbial sources of $\mathrm{N}_{2} \mathrm{O}$ are still little understood and partly contradictory. Clearly, more research is needed to be able to design biochars for the purpose of $\mathrm{N}_{2} \mathrm{O}$ emission reduction not only in soils, but also when using biochar in the management of $\mathrm{N}$-rich agricultural (fertilizer) materials such as manures or composts (see sections 3.1 and 3.3).

\subsubsection{Long-term effects of biochar addition and in old charcoal-rich soils: what do we know?}

It is also still unclear how long $\mathrm{N}_{2} \mathrm{O}$ emission reductions may persist following biochar addition to soil; or if old, black-carbon rich soils that undergo a change in their physico-chemical properties (such as Amazonian or African Dark Earths) will have a lower or higher potential for mitigating $\mathrm{N}_{2} \mathrm{O}$ emissions compared to soils without biochar. While a lab study reported that aged biochar particles increased $\mathrm{N}_{2} \mathrm{O}$ emissions (Spokas 2013), the opposite was observed in an experiment with $>100$ year-old charcoal particles from a kiln site (Kömpf 2013). Hagemann et al. (2016) reported that biochar still significantly suppressed $\mathrm{N}_{2} \mathrm{O}$ emissions in the third season in the field compared to the corresponding control field site without biochar. More data are slowly emerging on old charcoalrich soils (e.g. from historic kiln sites, Borchard et al. 2014a; Hardy et al. 2016, 2017), and more Dark Earth sites besides those in the Amazon basin have now been identified (e.g. in Liberia and Ghana, Solomon et al. 2016). However, to our knowledge no experiments on $\mathrm{N}_{2} \mathrm{O}$ emissions and soil $\mathrm{N}$ transformations have yet been carried out on these long-term analogues compared to their adjacent native, non-black-carbon soils. For the overall question if using biochar does offer long-term benefits regarding $\mathrm{N}_{2} \mathrm{O}$ emission suppression, exploring long-term effects is likely of great importance, since reducing peak emissions in the first years will only be a small part over the long-term. Particularly, these longer- and long-term effects are completely underexplored, and deserve much more research attention in the near future.

\section{Effects of biochar application on soil $\mathrm{CH}_{4}$ fluxes}

\subsection{Mechanisms of $\mathrm{CH}_{4}$ fluxes: production and consumption in soils and net release to the atmosphere}

The two biotic processes that determine the net methane $\left(\mathrm{CH}_{4}\right)$ exchange between soils/ecosystems and the atmosphere are methane production by strictly anaerobic methanogenic Archaea (Methanogens) and methane consumption by methanotrophic bacteria (Methanothrophs). Methane production takes place in all anoxic environments where organic carbon is microbially degraded (Conrad 2007a, 2007b; Whalen 2005), for example in peatlands, lake sediments, flooded rice fields, in landfills, in the guts of ruminant animals, termites or Scarabaeidae larvae (Hackstein, Stumm 1994; Kammann et al. 2009). Methanogens derive their energy from $\mathrm{H}_{2}$ and carbon dioxide $\left(\mathrm{CO}_{2}\right)$ or acetate, formate, methanol or other primary and secondary alcohols and methylated compounds (Brasseur, Chatfield 1991; Conrad 1999). Methanogenesis is thermodynamically the least efficient process i.e. other reduction processes outcompete $\mathrm{CH}_{4}$ production, if the concentration of alternative electron acceptors, such as nitrate $\left(\mathrm{NO}_{3}^{-}\right)$, sulphate $\left(\mathrm{SO}_{4}^{2-}\right)$, iron ( $\left.\mathrm{Fe}(\mathrm{III})\right)$ and manganese $(\mathrm{Mn}(\mathrm{IV}))$, is high in relation to the input of organic substrates (Lovley, Phillips 1987; Oremland 1988; Conrad 1989). Spatial and temporal variation in $\mathrm{CH}_{4}$ can be large (e.g. Saarnio et al. 1997; Juutinen et al. 2003): Spatial variation in $\mathrm{CH}_{4}$ flux within different microsites of the same ecosystem (e.g. Saarnio et al. 1997) and between different ecosystem types (e.g. Saarnio et al. 2009). Water table and temperature are dominant controls on $\mathrm{CH}_{4}$ efflux in bogs and swamps whereas the effect of aquatic vascular plants (aerenchyma "ventilation") was the most important in fens or rice paddies (Turetsky et al. 2014). Besides the aerenchyma transport, $\mathrm{CH}_{4}$ can also be transported with the transpiration water stream in swamp tree species as shown by Terazawa et al. (2007). Many ${ }^{14} \mathrm{CO}_{2}$ experiments have shown that recently fixed $\mathrm{C}$ is rapidly delivered from plants to methanogens (e.g. Megonigal et al. 1999) but the amount of exuded carbon is many times lower than that delivered via litter formation (Saarnio et al. 2004).

Methane consumption in soils is also ubiquitous in all terrestrial environments (Hütsch 2001; Seiler et al. 1984), and human land-use changes such as deforestation, ploughing and $\mathrm{N}$ fertilization reduce the soil $\mathrm{CH}_{4}$ sink (Powlson et al. 1997). $\mathrm{Net}^{\mathrm{CH}_{4}}$ consumption is due to the activity of methanotrophic $\alpha$ - and $\gamma$-proteobacteria. Most methanotrophs use $\mathrm{CH}_{4}$ as the sole carbon source and need oxygen to be active (Conrad 2007a). In upland soils, methane oxidation is largely determined by the soil diffusivity for $\mathrm{CH}_{4}$ and $\mathrm{O}_{2}$ (Castro et al. 1994, 1995). According to their $\mathrm{CH}_{4}$-oxidation kinetics, categories of "high-affinity" and "low-affinity" methanotrophs are often defined (Dunfield 2007). The first group occurs 
dominantly in upland soils and can consume atmospheric and sub-atmospheric $\mathrm{CH}_{4}$ concentrations (<1800 ppb), while low-affinity groups are found in anoxic environments (e.g. rice paddy soils) in the aerobic centimeters or millimeters of topsoil or in the oxygenated plant rhizospheres; these methanotrophs need higher $\mathrm{CH}_{4}$ concentrations. $\mathrm{CH}_{4}$ consumption can provide a "biofilter function" for environments with high $\mathrm{CH}_{4}$ production (rice paddies, landfill cover soils etc.).

\subsection{Biochar effects on $\mathrm{CH}_{4}$ production and release in net $\mathrm{CH}_{4}$-source soils}

The interactions between biochar application to soil and $\mathrm{CH}_{4}$ fluxes are not well understood, with disparate literature results (Jeffery et al. 2016; Song et al. 2016). Biochar application to paddy or flooded soils have been shown to increase (Yu et al. 2013; Zhang et al. 2012), decrease (Feng et al. 2012; Khan et al. 2013b; Lin et al. 2015; Qian et al. 2014), or have no significant effect on $\mathrm{CH}_{4}$ emissions (Xie et al. 2013). In anaerobic environments, the labile $C$ pool of biochar may theoretically function as methanogenic substrate, promoting $\mathrm{CH}_{4}$ production (Zhang et al. 2010). However, the labile $\mathrm{C}$ pool of root exudates and root litter is by far larger, thus labile biochar $\mathrm{C}$ may only play a role (i) initially, (ii) when the biochar has been produced at low temperature (i.e., greater labile $\mathrm{C}$ fraction), (iii) in bare/fallow soils without root carbon supply, and (iv) when the biochar amount added is great ( $>40 \mathrm{t} / \mathrm{ha}$ ) (Saarnio 2016). As an example, Zhang et al. (2012) did not observe increased soil $\mathrm{CO}_{2}$ efflux over two consecutive rice cropping years with 10-40 $\mathrm{t} \mathrm{ha}^{-1}$ biochar amendments, but significantly reduced $\mathrm{N}_{2} \mathrm{O}$ emissions at increased $\mathrm{CH}_{4}$ emissions; thus labile biochar- $\mathrm{C}$ is an unlikely explanation. Biochar was reported to also promote methanotrophic $\mathrm{CH}_{4}$ consumption at oxic/anoxic interfaces in anoxic environments. This lowered the net $\mathrm{CH}_{4}$ emissions by the "biofilter" function of bacterial (low-affinity) $\mathrm{CH}_{4}$ oxidation before it escaped to the atmosphere. When methanotrophic organisms increasingly oxidise $\mathrm{CH}_{4}$ in the presence of biochar at the oxic/anoxic root interface, they lower the amount of $\mathrm{CH}_{4}$ that can enter into the plants' aerenchyma to escape (Feng et al. 2012).

In a greenhouse mesocosm study with sewage sludge biochar (high application rates of $5 \%$ and $10 \%$ ), rice yield increased while the paddy soil turned from a net $\mathrm{CH}_{4}$ source to a net $\mathrm{CH}_{4}$ sink; this occurred in both rice-planted and bare paddy soil. These results may have been due to the addition of electron-accepting ash substances or nitrate with the sewage sludge biochar. In biochar-amended landfill cover soil, an increased $\mathrm{CH}_{4}$ oxidation activity was responsible for decreasing $\mathrm{CH}_{4}$ efflux from greater landfill depths (Sadasivam, Reddy 2015; Reddy et al. 2014). Here, the physico-chemical properties including air conductivity were considerably increased by biochar, i.e. the biochar effect might have been to improve the $\mathrm{O}_{2}$ supply to methane oxidizers. A recent meta-analysis (Song et al. 2016) of $\mathrm{CH}_{4}$ emissions reported that biochar application caused no pronounced change in $\mathrm{CH}_{4}$ emissions overall but that there was significant increase in methane emissions $(+19 \%)$. In another recent meta-study including papers up to December 2015, Jeffery et al. (2016) reported that biochar amendment to flooded and/or acidic soils had the potential to significantly reduce $\mathrm{CH}_{4}$ emissions. These two meta-studies differ in their conclusions, which may be due to a different database and meta-analytical approach.

Biochar impacts on natural net-methanogenic environments such as salt flats and wetlands are even less well understood. Owing to the longevity of biochar and its potential mobility and migration from anthropogenic systems, it will likely migrate to coastal areas over the longterm (as recently shown for dissolved pyrogenic organic carbon, Jaffé et al. 2013). Lin et al. (2015) investigated biochar application to saline costal soils where soybean and wheat was grown. They did not find any significant effect of biochar application to such soils on the (overall low) $\mathrm{CH}_{4}$ emissions, but they observed a yield increase of 24 and $28 \%$ in soy and wheat, respectively. In rice field studies, reductions in $\mathrm{CH}_{4}$ and/or $\mathrm{N}_{2} \mathrm{O}$ emissions were also often accompanied with increases in crop yields by between 10 and 20\% (Dong et al. 2015; Khan et al. 2013a; Zhang et al. 2012), resulting in a reduced greenhouse gas intensity per kg of rice grain.

Biochar implementation may also reduce the GHG intensity per unit of agricultural product by reducing $\mathrm{N}$-fertilizer and labile-C inputs at unaltered or increased yields. Qian et al. (2014) reported that the use of 4 different biochar-compound fertilizers made of chemical fertilizers, biochar and bentonite, at rates of well below $1 \mathrm{t}$ biochar ha ${ }^{-1}$, significantly improved the GHG intensity of a rice crop (by 36-56\%) by: 1) the biochar-compound fertilizer increasing grain yields by $10-31 \%$; and 2) reducing $\mathrm{CH}_{4}$ emissions by $25-50 \%$ and $\mathrm{N}_{2} \mathrm{O}$ emissions by 17-39\%. These results coincided with a reduced overall $\mathrm{N}$ fertilizer input, from $210 \mathrm{~kg} \mathrm{~N}$ to $168 \mathrm{~kg} \mathrm{~N} \mathrm{ha}^{-1}$, and without taking the $\mathrm{CO}_{2}$-equivalents of reduced fertilizer production and use into account (Qian et al. 2014). Thus, there is a considerable potential for reducing the GHG intensity of rice crop production, particularly in acidic soils (Jeffery et al. 2016), and that this potential extends beyond the C-sequestration potential. Large amounts of biochar do not need to be used at once since improvements were found at biochar rates $<1 \mathrm{t} \mathrm{ha}^{-1}$ (Qian et al. 2014). Therefore, three central research topics emerge here: (1) More research is needed on mechanisms of $\mathrm{CH}_{4}$ (and $\mathrm{N}_{2} \mathrm{O}$ ) emission reductions with biochar use from paddy and anaerobic soils including the effects on the "methanotrophic biofilter"; (2) Dedicated research on 
biochar-effect-mechanism systematics to design biochars with desired properties (Thomazini et al. 2015); and perhaps most importantly (3) Research on biochar compound fertilizers or underfoot fertilizers (Schmidt et al. 2015), to achieve higher yields at reduced GHG emissions and reduced $\mathrm{N}$ fertilizer use.

\subsection{Biochar effects on net $\mathrm{CH}_{4}$ consumption in oxic upland soils}

Well-aerated upland soils are characterised by $\mathrm{CH}_{4}$ consumption, mediated by methanotrophic bacteria. Forest, grassland and arable land have been described as $\mathrm{CH}_{4}$ sinks with flux rates of up to $65 \mu \mathrm{g} \mathrm{CH}_{4} \mathrm{~m}^{-2} \mathrm{hr}^{-1}$ (Dalal et al. 2008; Kern et al. 2012; Wang et al. 2005). As outlined above, in oxic/anoxic soil interfaces with a considerable $\mathrm{CH}_{4}$ source strength, where the methane oxidiser community is dominated by low-affinity methanotrophs, significant increases in methanotrophic abundance and/or activity have been reported following biochar amendment (Feng et al. 2012; Reddy et al. 2014; Sadasivam, Reddy 2015). However, upland soils mostly host high-affinity methanotrophs, capable of consuming atmospheric methane. Species composition and biology is different to that from anoxic soils (Dunfield 2007), and the $\mathrm{CH}_{4}$-consuming activity is quite easily hampered by human "activities" such as land conversion (particularly deforestation), N fertilization and ploughing. The number of studies using upland soils and measuring $\mathrm{CH}_{4}$ consumption with/without biochar is currently not large. Kollah et al. (2015) observed significantly increased $\mathrm{CH}_{4}$ consumption rates in a lab study with tropical soil amended with biochar (with or without organic amendments), as did Karhu et al. (2011) in in-field boreal, ploughed grassland soil. Karhu et al. (2011) assumed that the observed doubling of the $\mathrm{CH}_{4}$ consumption in the ploughed grassland soil was due to altered gas diffusivity and water holding capacity (which increased by $11 \%$ ). However, the effects may also be connected to increased $\mathrm{N}$ mineralization which usually occurs after ploughing, and where biochar may have prevented $\mathrm{N}\left(\mathrm{NH}_{4}^{+}\right)$inhibition by sorbing $\mathrm{NH}_{4}^{+}$(Taghizadeh-Toosi et al. 2012). Schimmelpfennig et al. (2014) observed increased $\mathrm{CH}_{4}$ consumption in clay loam soil under laboratory condition; however, in the field this was only present in tendency. Similarly, Scheer et al. (2011) did not observe increased soil $\mathrm{CH}_{4}$ consumption in a subtropical pasture that had been amended by $10 \mathrm{t} \mathrm{ha}^{-1}$ manure biochar in Australia.

In their meta-analysis, Song et al. (2016) reported high levels of uncertainty for $\mathrm{CH}_{4}$ oxidation in upland soils, while Jeffery et al. (2016) concluded that biochar addition may reduce the $\mathrm{CH}_{4}$ sink in neutral to alkaline upland soils. Over all data sets, biochar had a $\mathrm{CH}_{4}$ sinkincreasing (or source-decreasing) effect in soils fertilized at rates $<120 \mathrm{~kg} \mathrm{~N} \mathrm{ha}^{-1}$. Translated to upland soils this indicates that, when true high-affinity methanotrophic activity is present, it may be increased by biochar application. However, when high $\mathrm{N}$ application rates are used this was not the case (Jeffery et al. 2016); with high $\mathrm{N}$ fertilization the $\mathrm{CH}_{4}$-oxidising activity of an agricultural soil is often considerably reduced or completely shut down, likely due to nitrifiers replacing methanotrophs. In this case, the methanotrophic population would not be supported or improved. Taken together, the effects of biochar amendment on soil $\mathrm{CH}_{4}$ consumption are not well understood. Here, mechanistic studies are missing in particular, and thus should be a focus for future research.

\section{GHG emission reduction in animal husbandry and waste management using biochar}

After nearly a decade of research where biochar was solely added to soil to assess GHG fluxes, there is a shifting perception, that biochar may also be used as a tool to achieve GHG emission reductions during the handling and management of organic nutrient-rich materials such as manures. This section focuses on the use of biochar in animal husbandry and in composting or plant-substrate production (the topic of peat replacement is addressed by Kern et al. 2017, this issue). In Germany, Austria and Switzerland about $90 \%$ of the traded biochar is used in animal husbandry, mainly as feed additive (in the way activated carbon is used). However, to date, this topic has been nearly neglected in biochar research.

\subsection{Biochar as additive for feed and manure treatment in animal farming to reduce the emission of GHG}

Charcoal has been used to treat digestive disorder in animals for several thousand years. Cato the Elder (234-149 BC) mentioned it in his classic On Agriculture: "If you have reason to fear sickness, give the oxen before they get sick the following remedy: 3 grains of salt, 3 laurel leaves, [...], 3 pieces of charcoal, and 3 pints of wine." (Cato 1935, \$70; O’Toole et al. 2016). At the end of $19^{\text {th }}$ to beginning of the $20^{\text {th }}$ century, charcoal was increasingly used on a regular base to increase animal performance and health (PSAC 1905; Day 1906; Savage 1917; Totusek, Beeson 1953; Volkmann 1935). Later during the last century, veterinarian research focused on activated charcoal trials mostly in the form of time-restricted medications against intoxication and bacteriological as well as viral diseases (Toth, Dou 2016; Schmidt et al. 2016). Only since about 2010 has biochar increasingly been used as regular feed additive in animal farming (O'Toole et al. 2016), usually mixed with standard feed at approximately $1 \%$ of the daily feed intake. While scientists and farmers gained most of the results and experience in cattle and chicken farming, biochar is also administered to sheep, goats, pigs, horses, rabbits, cats, dogs and extensively in fish farming (Toth, 
Dou 2016; Schmidt et al. 2016). In a German review paper, Schmidt et al. (2016) evaluated more than 100 scientific papers on feeding biochar to various animal groups. Most of the studies showed for all investigated livestock species, positive (but not always significant) effects on parameters such as toxin adsorption, digestion, blood values, feed-use efficiency, cell numbers in milk and livestock weight gain; the latter may result from the $\mathrm{pH}$-increasing effect of various biochars since these are mostly alkaline in nature (see 3.3). Buffering the $\mathrm{pH}$ in the rumen could likely prevent acidosis which is known to impact livestock weight gain. However, only a small number of researchers measured GHG emissions.

While chicken, pigs, fish and other omnivore animals provoke GHG emissions (mainly $\mathrm{CH}_{4}, \mathrm{~N}_{2} \mathrm{O}$; and $\mathrm{NH}_{3}$ ) when their liquid and solid excretions decompose anaerobically, ruminants cause direct methane emissions through flatulence and burps (eructation). This is especially the case for cattle that emit daily 500 to $600 l$ gas with an average methane content between 6 and $8 \%$. The earliest evidence that feeding of biochar might reduce cattle methane emissions came in a 2012 Vietnam study (Leng et al. 2012a). In-vitro studies revealed significant methane reductions of 10 to $12.7 \%$ when biochar was fed at rates between 0.5 and $1 \%$. If biochar was blended with nitrate, methane emissions were reduced by up to $49 \%$. Nitrate becomes a strong electron acceptor in the anaerobic rumen, keeping the hydrogen potential low, and thus replacing a function of methane producing microorganisms. Vongsamphanh et al. (2015) also found in in-vitro tests with $1 \%$ biochar, while using cassava in rumen fluid, a $7 \%$ reduction of methane emissions within $24 \mathrm{~h}$. In-vivo trials of Leng et al. (2012b) revealed a reduction of enteric methane of cattle by $20 \%$ with feeding $0.6 \%$ biochar and by $40 \%$ with feeding $0.6 \%$ biochar blended to $6 \%$ potassium nitrate, leading to a highly significant animal weight increase of $25 \%$ over 98 days. This is by far the most spectacular result in reducing enteric cattle methane, but it has unfortunately not yet been supported by other in-vivo or in-vitro trials. Hansen et al. (2012) published the results of an in-vitro trial with various non-characterized biochars and their effect on methane production in rumen liquids. All tested biochars showed a trend to reduce methane emissions between $11 \%$ and $17 \%$. Other groups have not repeated Leng and colleagues' promising results. The reason could be that Leng and colleagues used high temperature gasifier biochars made from rice husk, resulting usually in carbonaceous materials with high electric conductivity and electron buffering capacity (Yu et al. 2015) which may have had a stronger influence on the digestion reactions electrochemically than woody biochar. Using biochar feeding to reduce ruminant methane emissions is currently only an interesting perspective that needs more systematic research.
Methane adsorption capacity by biochar is typically the most investigated pathway for explaining effects when fed to animals, but adsorption cannot explain all observations. Another decisive complementary function of biochar is its electro-biochemical interaction with biological active systems, with research only recently beginning. Biochars that are produced at temperatures above $700{ }^{\circ} \mathrm{C}$ are not only good electrical conductors (Yu et al. 2015; Mochidzuki et al. 2003) but can take part in biotic and abiotic redox-reactions as an electron mediator (Husson 2013; Kluepfel et al. 2014; Joseph et al. 2015a; Liu et al. 2012; Shi et al. 2016; Van der Zee, Cervantes 2009; Yu et al. 2015; Kappler et al. 2014). A well balanced animal feed regime contains multiple electron mediating substances, however, in the high energetic diets of intensive livestock farming these compounds are often not contained in sufficient amounts (Sophal et al. 2013). If in these cases inert or other non-toxic electron mediators like biochar, wood vinegar or humic substances are added to the feed, many redox reactions may take place more smoothly and efficiently which could increase energy conversion efficiency and thus feed efficiency (Liu et al. 2012; Leng et al. 2013), and eventually decrease enteric and post digestive GHG production. Particularly, lowering $\mathrm{CH}_{4}$ emissions (which are always a sign of energy loss) may be aided by the electron shuttling abilities of biochar. Moreover, it might be assumed that the buffering of the redox-potential as well as the effect of electron shuttling between various microbial species has a selective, milieu forming effect which facilitates and accelerates the formation of functional microbial consortia and syntrophic species (Kalachniuk et al. 1994). The latter could explain why several studies found a strong increase of Lactobacilli or a decrease of gramnegative bacteria (Naka et al. 2001; Choi et al. 2009) which seems to improve animal health. Thus, it may be hypothesized that direct electron transfers between different species of bacteria or microbial consortia (Chen et al. 2014) via a biochar mediator may aid in a more energy efficient digestion and thus higher feed efficiency and eventually result in lower GHG emissions (Leng et al. 2012a, 2012b).

When animals receive charcoal feed additives combined with Lactobacilli spraying (i.e. microbial milieu management in the stable), it is interesting to note that antibiotic use may be reduced and in some cases down to zero. Farmers in Germany who use this practice frequently report reduced veterinarian costs (Kammann, pers. comm.) that "pay" for the use of biochar and Lactobacilli solution. Reduced antibiotics may also reduce $\mathrm{CH}_{4}$ emissions from ruminant husbandry. Recently, Hammer et al. (2016) showed that application of broad-spectrum antibiotics enhanced $\mathrm{CH}_{4}$ emissions from cattle manure, and altered the gut microflora from dung beetles feeding on the manure from cows treated with broad-spectrum antibiotics. As Choi et al. (2009) and Islam et al. (2014) 
showed that feeding 0.3 to $1 \%$ biochar could replace antibiotic treatment in chicken and ducks, respectively, feeding biochar plus administering Lactobacilli could have an indirect effect on GHG emissions when it is able to replace regular antibiotic "feeding". Furthermore, Joseph et al. (2015b) demonstrated that feeding biochar to grazing cows had positive secondary effects on soil fertility and fertilizer efficiency, reducing mineral $\mathrm{N}$-fertilizing requirements which could be construed as another indirect biochar GHG mitigation effect. Thus, enabling farmers to stop or reduce administering antibiotics by using biochar and Lactobacilli may be promising, not only for animal health, but also for reducing methane emissions from animal husbandry operations (Hammer et al. 2016).

\subsection{Calculating $\mathrm{CO}_{2}$-equivalent balances of biochar use in animal husbandry: first considerations}

Besides the possible effects of biochar feeding on ruminant $\mathrm{CH}_{4}$ emissions, it is not unlikely that microbial decomposition of manure containing digested biochar produces less ammonia, less $\mathrm{CH}_{4}$ and thus retains more nitrogen. This has been observed between manure composted with and without biochar (section 3.3; e.g., Sonoki et al. 2013; Steiner et al. 2010; Troy et al. 2013; Wang et al. 2013b) and may also occur when biochar is used as bedding or manure treatment additive. Ghezzehei et al. (2014) estimated that using biochar for liquid manure treatment could save $57,000 \mathrm{t} \mathrm{NH}_{4}$ and 4,600 $\mathrm{t}_{2} \mathrm{O}_{5}$ fertilizer per year in California alone, though this estimate is only based on laboratory adsorption tests and not on field trials. However, it cannot be excluded that digested biochar will not have the same effect on microbial decomposition, GHG emissions and plant nutrient retention as when production-fresh biochar is applied to the bedding or manure pit. To our knowledge, there are no published data on GHG-emissions in animal housing and of manure pits after feeding animals with biochar.

Easier to calculate is the C-sequestration potential of biochar that is first fed to livestock and eventually applied to soil with the manure. Assuming an average C-content of fed biochar of $80 \%$, as required by the EBC feed certificate (EBC 2012) and produced at recommended temperatures above $500{ }^{\circ} \mathrm{C}$ resulting in $\mathrm{H} / \mathrm{C}_{\text {org }}$ ratios below 0.4 , at least $56 \%$ of the dry weight of the fed and manure-applied biochar will persist as stable carbon in soil for at least 100 years (Lehmann et al. 2015). If the global livestock would, just theoretically and for the sake of a "back-of-the envelope" assessment to explore magnitudes, receive $1 \%$ of their feed in form of such a biochar, about 400 Mio. $t$ of $\mathrm{CO}_{2}$ eq or $1.2 \%$ of the global $\mathrm{CO}_{2}$ emissions could be compensated (Table 1).

While the feeding of "vegetal carbon" (biochar) is permitted in the EU (EU 2011), it certainly cannot be recommended yet as in a generalized biochar-livestock feeding regime, since feed-grade certification of biochar is currently not established in most countries and since long-term effects are not sufficiently investigated. However, the potential for improving animal health and nutrient efficiency, for reducing enteric methane emissions as well as GHG emissions from manure management, and for sequestering carbon while improving soil fertility improvements, calls for increasing the scientific effort to investigate, measure and optimize the GHG reduction potential of biochar use in animal farming systems. The use of biochar in animal husbandry is one of the largest unexplored research topics within the biochar research realm. Although many unknowns and open questions exist, biochar use in animal operations appears promising from a GHG reduction standpoint and thus future research could focus efforts towards this area.

Table 1. Carbon sequestration potential of biochar fed to livestock (globally) with subsequent manure application to soil. Numbers of total livestock follow FAO statistics obtained for 2014 (FAO 2016). An intake dosage of 1\% of the daily feed weight was assumed. The $\mathrm{C}$ sequestration potential was calculated with the assumption of $80 \% \mathrm{C}$ in biochar, and $70 \% \mathrm{C}$ persistence over 100 years (Lehmann et al. 2015; Camps-Arbestain et al. 2015)

\begin{tabular}{|c|c|c|c|c|c|c|}
\hline Animal & $\begin{array}{l}\text { Global number of } \\
\text { individual animals }\end{array}$ & $\begin{array}{l}\text { Daily intake dosage } \\
\left(\mathrm{g} \mathrm{bc} \text { animal }^{-1} \mathrm{~d}^{-1}\right)\end{array}$ & $\begin{array}{l}\text { Annual intake dosage } \\
\left(\mathrm{kg} \mathrm{bc} \text { animal }{ }^{-1} \mathrm{yr}^{-1}\right)\end{array}$ & $\begin{array}{l}\text { Total biochar } \\
\left(\text { Mio. } \mathrm{t} \mathrm{yr}^{-1}\right)\end{array}$ & $\begin{array}{l}\text { Total C seq. } \\
\left(\text { Mio. } \mathrm{t} \mathrm{yr}^{-1}\right)\end{array}$ & $\begin{array}{l}\text { Total } \mathrm{CO}_{2} \mathrm{ec} \\
\left(\text { Mio. } \mathrm{t} \mathrm{yr}^{-1}\right)\end{array}$ \\
\hline Cattle & $1,482,144,415$ & 120 & 43.8 & 64.9 & 36.4 & 133.3 \\
\hline Buffaloes & $195,098,316$ & 120 & 43.8 & 8.5 & 4.8 & 17.5 \\
\hline Sheep & $1,209,908,142$ & 50 & 18.25 & 22.1 & 12.4 & 45.3 \\
\hline Goats & $1,006,785,725$ & 50 & 18.25 & 18.4 & 10.3 & 37.7 \\
\hline Pigs & $986,648,755$ & 80 & 29.2 & 28.8 & 16.1 & 59.2 \\
\hline Horses & $58,913,957$ & 120 & 43.8 & 2.6 & 1.4 & 5.3 \\
\hline Chickens & $21,321,834,000$ & 6 & 2.19 & 46.7 & 26.1 & 95.9 \\
\hline Turkeys & $461,453,000$ & 6 & 2.19 & 1.0 & 0.6 & 2.1 \\
\hline Total & & & & 193.0 & 108.1 & 396.3 \\
\hline
\end{tabular}




\subsection{Biochar as composting additive}

Composting is the aerobic biotic oxidation of organic residue, manure and waste for producing organic fertilizer and occasionally waste management. Labile organic carbon is transformed into humic like substances and $\mathrm{CO}_{2}$, with $\mathrm{N}_{2} \mathrm{O}$ and $\mathrm{CH}_{4}$ as non-desired by-products. Emission rates of $\mathrm{N}_{2} \mathrm{O}$ and $\mathrm{CH}_{4}$ depend on compost management, and increase with increasing degrees of anoxia during composting. During a perfect aerobic quality composting procedure, $\mathrm{N}_{2} \mathrm{O}$ and $\mathrm{CH}_{4}$ emissions are usually low (Amlinger et al. 2003, 2008; Bernal et al. 2009). However, aerobic conditions cannot always be perfectly maintained, particularly when manure-rich waste is composted; here larger $\mathrm{N}_{2} \mathrm{O}$ and $\mathrm{CH}_{4}$ emissions are common (Li et al. 2016; Wang et al. 2013b). Thus, it is desirable to develop strategies to reduce GHG emissions during composting, particularly of nutrient-rich wet materials.

With regard to biochar, "co-composting" refers to the addition of biochar to the initial composting feedstock. During co-composting, biochar can sorb compost liquids rich in nutrients, particularly nitrate (Prost et al. 2013; Kammann et al. 2015). Furthermore, some studies report an accelerated thermophilic phase with higher compost temperatures (Kammann et al. 2016; Vandecasteele et al. 2016). $\mathrm{CO}_{2}$ emissions are an obligate result of composting due to the decomposition of labile organic matter. This loss during composting ranges from $\sim 40 \%$ (Vandecasteele et al. 2016) to 80\% (Sánchez-García et al. 2015) depending on the compost feedstock and composting conditions. Some studies show no effect of biochar on $\mathrm{CO}_{2}$ emissions or increases of emission rates (Steiner et al. 2011; LópezCano et al. 2016). However, Malinska et al. (2014) and Vandecasteele et al. (2016) reported a reduction of $\mathrm{CO}_{2}$ emissions. Vandecasteele et al. (2016) argue that pristine biochar used in their experiments might have physically adsorbed $\mathrm{CO}_{2}$ (Creamer et al. 2014; Fornes et al. 2015) and thus reduced $\mathrm{CO}_{2}$ emissions, although actual $\mathrm{CO}_{2}$ production probably increased (e.g., increase of decomposition, higher temperatures). However, a faster rate of C loss does not necessarily mean that, overall, biochar will reduce the long-term storage of non-pyrolyzed feedstock in soils; it just means that a process that happens otherwise over longer periods is accelerated.

$\mathrm{CH}_{4}$ and $\mathrm{N}_{2} \mathrm{O}$ emissions from compost are non-desired side effects and can be reduced by adequate management of the composting process with regard to oxygen supply, including windrows not exceeding certain sizes, optimized water content and forced or mechanical aeration (Fukumoto et al. 2003; Amlinger et al. 2008). However, these management strategies can be costly. Recent studies indicate that biochar addition during the composting process can indeed reduce emissions of both $\mathrm{CH}_{4}$ and $\mathrm{N}_{2} \mathrm{O}$ probably due to enhanced access of oxygen mediated by biochar. Methane emissions are often drastically reduced by biochar addition, with reported reduction rates of $55 \%$ for chicken manure compost with biochar added at $20 \%$ w/w (Jia et al. 2016), >70\% for organic waste compost with biochar added at $10 \%$ rate (Sonoki et al. 2011), and $>80 \%$ for municipal solid waste compost with biochar added at $10 \% \mathrm{w} / \mathrm{w}$ (Vandecasteele et al. 2016). However, at low biochar additions (e.g. 3\%), Sánchez-García et al. (2015) observed no significant effect on $\mathrm{CH}_{4}$ emissions during the composting process, suggesting that a certain biochar rate during composting is necessary to reach desired reductions in $\mathrm{CH}_{4}$ emissions.

Gaseous N losses also often decrease when biochar is used as an additive during the composting process since the $\mathrm{pH}$ of composts does usually stay below or around
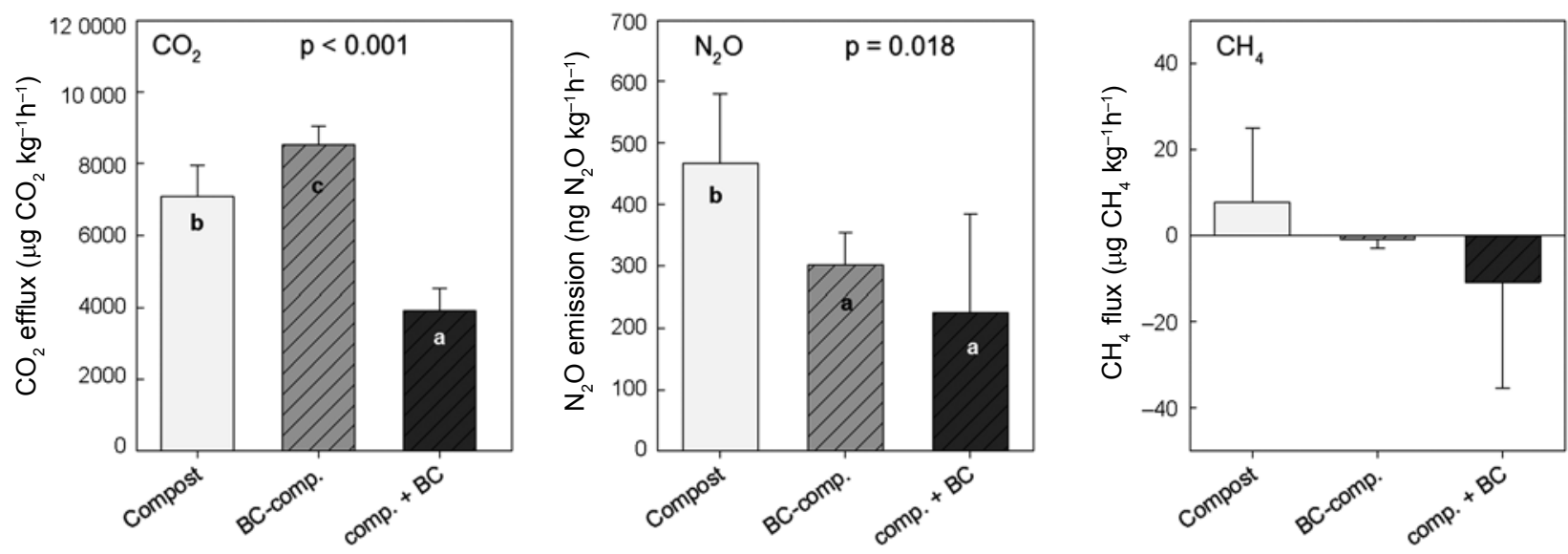

Fig. 2. Mean GHG flux rates of compost (comp), biochar-compost (BC-comp) and compost with later addition of fresh biochar $\left(\right.$ comp + BC), $\mathrm{n}=5+$ standard deviation; GHG flux measurements with 400 g substrate per 1-L Weck ${ }^{\otimes}$ jar as described in Kammann et al. (2012); Material properties and composting procedure described in Schmidt et al. (2014) and Kammann et al. (2015). Substrates were adjusted to $60 \%$ of their respective water-holding capacity one week before measurement. Letters indicate significant differences by one-way ANOVA $(n=5, p<0.05)$ 
$\mathrm{pH}$ 7.5. However, care has to be taken to prevent a strong $\mathrm{pH}$ increase due to (large amounts of) biochar addition in composting, with animal bedding, manure treatment or elsewhere. If values above a $\mathrm{pH}$ of 8 are reached, $\mathrm{NH}_{3}$ losses may result which was systematically investigated by Chen et al. (2013) with biochar additions up to $20 \%$ by weight to bauxite processing sands in a $\mathrm{pH}$-adjusted set-up of $\mathrm{pH}$ values ranging from 5 to 9 . The authors reported that at low and high $\mathrm{pH}$ values, $\mathrm{NH}_{3}$ losses were increased by biochar additions (at low $\mathrm{pH}$ when the addition of biochar was sufficiently large to provoke a $\mathrm{pH}$ increase), while at a high $\mathrm{pH} \mathrm{NH}$ losses were high anyway. However at a more neutral $\mathrm{pH}$, the $\mathrm{NH}_{4}{ }^{+}$adsorption capacity of biochar dominated which decreased $\mathrm{N}$ losses (Chen et al. 2013). However, the first available results are contradictory: While Schimmelpfennig et al. (2014) found a reduction of $\mathrm{NH}_{3}$ emissions when slurry was added to a loam soil ( $\mathrm{pH}$ 6.0) amended with biochar when compared to the same soil amended with (less alkaline) straw, Subedi et al. (2015) reported an increase in the $\mathrm{NH}_{3}$ emissions from slurry when both, an alkaline biochar and an acidic hydrochar were added to the slurry. It is possible that the overall "evaporation surface" which may increase by adding a bulky material to soil or slurry may also play a role for increasing $\mathrm{NH}_{3}$ losses. Nevertheless, the biochar-doseto-pH-increase relationship should always be taken into account.

Studies conducted with relatively low dosages of biochar (e.g. 3-4\%) showed either a reduction in $\mathrm{N}_{2} \mathrm{O}$ emission (Wang et al. 2013a; Li et al. 2016) or no effect (Sánchez-García et al. 2015; López-Cano et al. 2016). When reductions in $\mathrm{N}_{2} \mathrm{O}$ emissions were observed, they were pronounced but happened only during a portion of the composting process. For example, Li et al. (2016) reported that 3\% biochar addition during composting reduced $\mathrm{N}_{2} \mathrm{O}$ emission by $54 \%$, which was entirely attributable to $\mathrm{N}_{2} \mathrm{O}$-peak suppression for only one of the eight measurement dates. This effect was further attributed to a marked reduction in the abundance of the nirK gene of denitrifying bacteria when biochar was co-composted (Li et al. 2016).

Ammonia $\left(\mathrm{NH}_{3}\right)$ is not a greenhouse gas, but a relevant atmospheric precursor of $\mathrm{N}_{2} \mathrm{O}$ (shown in section 1.2), and its volatilization during composting is a relevant pathway for $\mathrm{N}$ loss. Biochar amendment was shown to reduce $\mathrm{NH}_{3}$ volatilization particularly in $\mathrm{N}$-rich materials such as sludge or manures, probably due to $\mathrm{NH}_{4}^{+}$sorption (Chen et al. 2010; Hua et al. 2009; Steiner et al. 2010; Malinska et al. 2014). Increased $\mathrm{N}$ content in the compost, in the form of $\mathrm{NH}_{4}^{+}$, is a desired property for compost use as an organic fertilizer. When applied to soil, the larger quantity of $\mathrm{N}$ and labile $\mathrm{C}$ retained in the composted biochar particles (or in the biochar-compost product) may theoretically lead to higher $\mathrm{N}_{2} \mathrm{O}$ emissions as compared to pure, non-composted biochar (Prost et al. 2013; Borchard

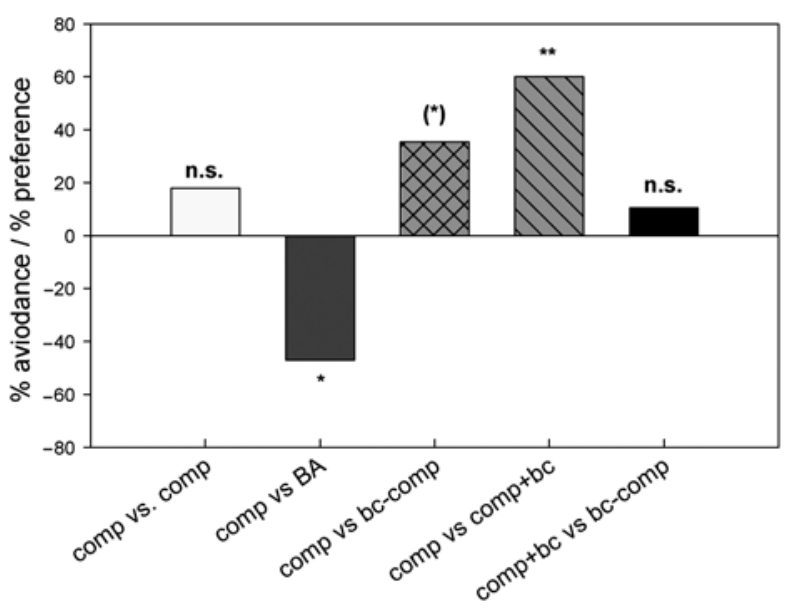

Fig. 3. Results of earthworm avoidance tests (method: ISO 17512-1:2008; Busch et al. 2012) with the compost (comp), biochar-compost (bc-comp) and compost with later addition of fresh biochar $(\mathrm{comp}+\mathrm{bc})$, material properties and composting described in Schmidt et al. (2014) and Kammann et al. (2015). "Comp vs. comp" is the control and did not result in an effect (as needed); boric acid (BA) was the "positive control" where avoidance behaviour confirmed that the test was valid. Bars give means of $n=5$ repetitions per treatment ( 50 worms), shown as preference or avoidance of the respective substrate (Fishers exact test, $\left({ }^{*}\right) \mathrm{p}<0.1,{ }^{\star} \mathrm{p}<0.05,{ }^{* *} \mathrm{p}<0.01$, n.s. not significant)

et al. 2014b). This was, however, not observed in a planting study using co-composted (nitrate-enriched) biochar as soil amendment (Kammann et al. 2015), or when the compost itself was tested (Fig. 2).

At the moment, results are just snapshots of first composting experiments with biochar, and studies include a wide range of experiments from $150 \mathrm{~g}$ mixtures in jars (Jia et al. 2016), 45 L composting reactors (Malinska et al. 2014), $1 \mathrm{~m}^{3}$ gardening compost boxes (Prost et al. 2013) to $60 \times 3 \times 2 \mathrm{~m}$ windrows with forced aeration and automated mechanical turning (Vandecasteele et al. 2016) or daily machine turning (Schmidt et al. 2014; Kammann et al. 2015) at varying time scales (few weeks to several months). Generally, the value of composting studies would be increased if the resulting compost quality is subsequently evaluated by plant germination and growth tests (e.g. Hua et al. 2012, soil faunal tests, e.g. Fig. 3) and field application trials.

Biochar is a promising tool to optimize composting, improve compost quality and charge biochar with plantavailable nutrients and reduce non- $\mathrm{CO}_{2}$ GHG emissions during composting. However, the longer-term effects of biochar-composts in soils are largely unexplored. More systematic studies with different combinations of $\mathrm{N}$-rich and $\mathrm{N}$-poor feedstock and different well-characterized biochars under comparable, praxis-relevant conditions are needed, and subsequently product quality and its effects on soil GHG emissions after soil amendment should be investigated. 


\section{Novel approaches of using biochar for GHG emission reductions in agriculture}

GHG emission reductions with biochar use may not necessarily be direct; rather, reductions may result from alternative waste stream management involving pyrolysis. Another option is to use biochar as a fertilizer carrier to match plant demands more closely, enabling the reduced use of common mineral fertilizers and hence associated $\mathrm{N}_{2} \mathrm{O}$ emissions (see 3.1, Qian et al. 2014). This section addresses novel biochar concepts for reducing the overall GHG intensity of agricultural production, including those from unwanted $\mathrm{NO}_{3}^{-}$and $\mathrm{NH}_{3}$ losses and deposition, causing $\mathrm{N}_{2} \mathrm{O}$ emissions elsewhere (Turner et al. 2015).

\subsection{Biochar as carrier for (organic) underfoot fertilizers}

The use of large biochar amounts (e.g. 10-20 tons) being ploughed into soils does usually not increase crop yields sufficiently to justify the costs (Jeffery et al. 2015; Biederman, Harpole 2013; Ruysschaert et al. 2016). Here, the economy of biochar use may be better for special crops as long as yield increases without negative effects on crop quality can be realized, as observed by Baronti et al. (2014) and Genesio et al. (2015) for grapevine cultures. However, grapevines are low- $\mathrm{N}$ cultures with low $\mathrm{N}_{2} \mathrm{O}$ emissions (Marras et al. 2015) compared to higher N-fertilizer demanding vegetable crops such as radish, carrot, spinach or potato. These receive much higher $\mathrm{N}$ fertilizer amounts, often with several cropping cycles per year, resulting in high $\mathrm{N}_{2} \mathrm{O}$ emissions (Ruser et al. 1998; Min et al. 2016). In highly fertilized vegetable crops, biochar amendment may play a role in significantly reducing the greenhouse gas intensity per unit of crop, likely by reducing $\mathrm{N}_{2} \mathrm{O}$ emissions and partly by yield increases (Jia et al. 2012; Li et al. 2015). However, use of biochar in these situations, as with others, comes with a cost.

In order to reduce costs, it is desirable to maximize the effect of biochar per unit applied, suggesting that optimum application rates might be fairly low especially if the product can be concentrated around the root zone. Indeed, root zone application of only $2-4 \mathrm{t} \mathrm{ha}^{-1}$, together with fertilizer in conservation farming systems, has been reported to improve yields in acidic sandy soils (Cornelissen et al. 2013). In addition, using biochar as an ingredient of, or carrier matrix for, mineral or organic fertilizer blends ("fertichars") has recently been investigated as a promising strategy to reduce the need for large biochar amounts while improving crop yields and/or reduce $\mathrm{N}$ use (Joseph et al. 2013). Supporting this contention, Qian et al. (2014) showed that biochar organo-mineral fertilizer blends reduced the GHG-intensity of rice crop production even at reduced $\mathrm{N}$ fertilization rates and at very low amounts of biochar $\left(<1 \mathrm{t} \mathrm{ha}^{-1}\right)$.
In practice, the on-farm availability of clean, inexpensive, and amounts required will decide whether biochar will be used, particularly in rural areas in developing countries (Cornelissen et al. 2013). In Nepal, a self-made organic "fertichar" was used as underfoot fertilizer in 8 different farmer sites (fertile loamy soils) and compared to the same nutrient additions without biochar. Here, pumpkin yields were consistently increased by $400 \%$ with the urine-loaded biochar applied as underfoot fertilizer, and multiple field trials on different soils, crops and biochar consistently showed a growth-promoting effect of the organic biochar-root zone fertilizer (Schmidt et al. 2015). It has not yet been tested if these biochar-fertilizer blends will reduce GHG emissions compared to an equal or greater amount of standard fertilizer. However, we argue that GHG emission reductions (namely those of $\mathrm{N}_{2} \mathrm{O}$ ) per unit of crop yield may be achieved for the following reasons: (1) The fertichar blends mean a comparatively high amount of biochar concentrated together with the nutrients, i.e. within the "biochar concentration range" found to reduce $\mathrm{N}_{2} \mathrm{O}$ emissions in soils considerably in meta-studies (Cayuela et al. 2014); (2) By stimulating plant growth, $\mathrm{N}$ uptake increases, which reduces the availability of $\mathrm{N}$ for nitrification / denitrification and hence $\mathrm{N}_{2} \mathrm{O}$ formation; (3) When applied underfoot, the total land area that receives $\mathrm{N}$ fertilizer and is able to produce $\mathrm{N}_{2} \mathrm{O}$ emissions is smaller; (4) By using root-zone fertichars, the overall amount of $\mathrm{N}$ fertilizer that needs to be applied, per unit of crop produced, can likely be reduced (Joseph et al. 2013; Qian et al. 2014). This may automatically reduce the GHG emissions (as a percentage of the applied fertilizer); and (5) Biochar will reduce the soil bulk density (e.g. Obia et al. 2016) and increase soil air capacity, which has been shown to reduce $\mathrm{N}_{2} \mathrm{O}$ production due to improved oxygen supply in upland soils. However, it is simply unknown if this type of application will reduce the GHG intensity of crop production and if this will occur on different soils and climatic zones alike. Further research is needed on fertilizer-biochars, either as broadcast granules (Qian et al. 2014) or as underfoot fertilizers (Schmidt et al. 2015), since these techniques may offer a win-win in terms of reducing GHG emissions concomitantly with improved yields.

\subsection{Pyrolysis as alternative waste stream management technique}

Over the past twenty years, localization of confined animal feeding operations (CAFOs) in the USA has brought about a massive production of animal manures (Gollehon et al. 2001). Traditional management practices have applied manure to crops as a fertilizer, yet long-term manure applications have caused nutrient imbalances in soils far in excess of what crops can assimilate (Barker, Zublena 
1995; Kellogg et al. 2000). The situation is so severe that CAFO producers must have nutrient management plans (e.g., MDE 2016; ISDA 2016) or manure application can be restricted if soils contain excess $\mathrm{N}$ and/or P. A clear need exists for alternate animal waste management and recycling methods.

Thermal processing of animal manures using gasification and pyrolysis technology is gaining considerable interest as an alternate treatment option because of the energy quantity generated (Cantrell et al. 2007, 2008). Manure gasification is a popular conversion process, yet the higher temperatures $\left(>900{ }^{\circ} \mathrm{C}\right)$ required for conversion into gases, along with impurities in the feedstocks (e.g. salts, silicates, etc.), oftentimes limits the conversion efficiency (Lv et al. 2010) and can corrode downstream metal surfaces (Demirbas 2005). Thus, pyrolysis is more often regarded as the effective method of processing biomass to produce a combination of non-condensable gases, bio-oil, and biochar (Antal, Grønli 2003). Manures can be pyrolyzed at various temperatures (e.g. 300 to $750{ }^{\circ} \mathrm{C}$ ) to create biochars. Afterwards, the energy content (as MJ/kg) contained within biochar identifies the quantity of energy generated per equivalent dry weight and serves as a convenient energy index relative to coal (Table 2). Globally, animal waste pyrolysis is performed to create a thermal energy source, to generate heat for animal confinement stables, for the production of bio-oil, and to produce biochar, a nutrient-enriched end-product to be used as a soil amendment (Laird et al. 2009; Lee et al. 2013) or fertilizer replacement.

Table 2. Net thermal energy in various manures, and their biochars pyrolyzed at various temperatures, as compared to hard/soft coals, gasoline and methane. na = not available

\begin{tabular}{lccl}
\hline \multirow{2}{*}{ Feedstock } & $\begin{array}{c}\text { Thermal } \\
\text { tempera- } \\
\text { ture }\left({ }^{\circ} \mathrm{C}\right)\end{array}$ & $\begin{array}{c}\text { Energy } \\
\text { content } \\
(\mathrm{MJ} / \mathrm{kg})\end{array}$ & \multicolumn{1}{c}{ Source } \\
\hline Poultry litter & 0 & 15 & Novak et al. $(2013)$ \\
\cline { 2 - 4 } Dairy manure & 700 & 14.2 & Novak et al. $(2013)$ \\
\cline { 2 - 4 } & 0 & 17.6 & $\begin{array}{l}\text { Cantrell } \text { et al. } \\
(2012)\end{array}$ \\
\hline Swine Solids & 0 & 19.4 & $\begin{array}{l}\text { Cantrell } \text { et al. } \\
(2012)\end{array}$ \\
\cline { 2 - 4 } & $350-700$ & $15.1-21.1$ & $\begin{array}{l}\text { Cantrell } \text { et al. } \\
(2012)\end{array}$ \\
\hline Human Feces & $300-750$ & $13.8-25.6$ & $\begin{array}{l}\text { Ward } \text { et al. } \text { (2014) } \\
(2012)\end{array}$ \\
\hline Hard/soft coal & na & $29.3-33.5$ & Euronuclear $(2016)$ \\
\hline Gasoline & na & $43-47$ & $\begin{array}{l}\text { Energynumbers } \\
(2005)\end{array}$ \\
\hline Methane & na & 55.5 & $\begin{array}{l}\text { Energynumbers } \\
(2005)\end{array}$ \\
\hline
\end{tabular}

Following manure pyrolysis, it has been shown by Gaskin et al. (2008) that nutrient availability may be decreased in the biochar, which may make manure-based biochar use attractive in terms of land areas where nutrient management plans are necessary; biochars may be able to supply a more balanced quantity of essential plant nutrients without degradation in environmental quality due to nutrient over-application. Furthermore, an additional benefit similar to previously mentioned underfoot fertilizer-biochars, manure-based biochar may significantly reduce overall farm-management based GHG emissions simply by reducing mineral fertilizer use (Cayuela et al. 2014; Nguyen et al. 2014).

The production of animal manure biochar via pyrolysis, and the subsequent partial or complete replacement of standard mineral NPK fertilization by manurebiochar, offers the following pathways to $\mathrm{N}_{2} \mathrm{O}$ emissions reduction: (1) Reduced $\mathrm{N}$ use which reduces the overall environmental burden by limiting $\mathrm{N}_{2} \mathrm{O}$ formation both from direct manure application as well as emissions originating from off-site $\mathrm{N}$ pollution (e.g. $\mathrm{NH}_{3}$ emissions, $\mathrm{N}$ export via overland flow, $\mathrm{N}$ leaching to groundwater, Turner et al. (2015); (2) The use of manure-based biochar may reduce $\mathrm{N}_{2} \mathrm{O}$ emissions compared to using the same amount of $\mathrm{N}$ in the mineral or manure form. Cayuela et al. (2014) examined 107 articles related to manure-based biochar land application, showing a -46 to $+39 \%$ change in $\mathrm{N}_{2} \mathrm{O}$ emissions, with average $\mathrm{N}_{2} \mathrm{O}$ emission changes close to $0 \%$. Thus, changes or reductions in $\mathrm{N}_{2} \mathrm{O}$ emissions is likely process dependent, something that was not examined by Cayuela et al. (2014). However, Subedi et al. (2016) added poultry litter or swine manure biochar to two different soils. The authors showed that poultry litter or swine manure biochars pyrolyzed at $400{ }^{\circ} \mathrm{C}$ produced the same $\mathrm{N}_{2} \mathrm{O}$ emission factor (i.e., $\mathrm{N}_{2} \mathrm{O}$ emitted as a percentage of the total $\mathrm{N}$ supplied) as control soils. When pyrolyzed at $600{ }^{\circ} \mathrm{C}$, the $\mathrm{N}_{2} \mathrm{O}$ emission factor decreased for both biochars as compared to controls. Higher temperatures during production will result in manure-based biochars containing lesser quantities of easily degradable $\mathrm{C}$ compounds (e.g., volatile compounds) that are available for denitrifiers, leading to less likelihood of anaerobic soil conditions (e.g., Liu et al. 2014) and thus lower $\mathrm{N}_{2} \mathrm{O}$ emissions. Obviously, in order to reduce $\mathrm{N}_{2} \mathrm{O}$ emissions when applying manure-based biochars, easily degradable $\mathrm{C}$ sources needs to be at a minimum; and (3) The use of pyrolysis for heat generation in animal housing, and/or the use of manure biochar for energy production, can be implemented to reduce GHG emissions when it replaces the use of fossil fuels for the same purpose (see energy content comparison in Table 2). 


\section{Conclusions: promising options for GHG emission reduction and future research needs}

After a decade of intense biochar research, it has become clear that biochar soil amendments are able to reduce $\mathrm{N}_{2} \mathrm{O}$ emissions (i.e. emission peaks). Biochar can also reduce $\mathrm{CH}_{4}$ emissions, particularly in flooded soils, and when $\mathrm{N}$ fertilization rates are not too high. However, great uncertainty still exists with respect to biochar use and its GHG reducing effect as associated with different biochars and soil types/conditions. This is due to the lack of understanding of mechanistic biochar effects. Good "candidate" mechanisms that might explain $\mathrm{N}_{2} \mathrm{O}$ emission reductions are $\mathrm{pH}$ increases (liming effect) and changes in microbial community composition, particularly changes in the denitrifier gene expression and abundance, and $\mathrm{N}$ (mostly nitrate) capture in biochar particles. It is likely that these mechanisms work in concert under field conditions. Good "candidate" mechanisms that might explain $\mathrm{CH}_{4}$ emission reductions are the stimulation of methanotrophic low-affinity communities at the anoxic/oxic interface in reduced environments as well as the electron shuttling and redox activity of biochars (e.g. rice paddies and ruminant guts).

Biochar use in animal husbandry is economically promising and the dominant route of biochar use in central Europe; however, research on GHG emission reductions is largely lacking. Studies dealing with the medical use of charcoal/biochar in animal feeding nearly never characterize char properties. Biochar shows a strong potential for reducing GHG and $\mathrm{NH}_{3}$ emissions in the composting of wet nutrient-rich materials, particularly when composts are not so frequently turned (aerated, i.e. "lazy composting"). Yet, more detailed studies on the dynamics of this effect along the composting process are needed, as well as a cost-benefit evaluation for potential implementation.

One new promising option of using biochar for improving the GHG-intensity (yield-to-GHG emission ratio), via both increasing yields plus reduced GHG emissions, may be the use of designed (organic) "FertiChars" (biochar as fertilizer carrier) administered as concentrated root zone fertilizers. Here the biocharto- $\mathrm{N}$ ratio may certainly be in the range where biochar should have an effect as well as effectively and environmentally deliver optimal nutrient concentrations to plants. However, to date, GHG flux measurements of this implementation pathway are lacking and strongly call for future research. We conclude that the use of biochar in agriculture provides a unique opportunity to reduce the non- $\mathrm{CO}_{2}$ greenhouse gas "cost" per unit of yield produced, yet future research is required to maximize its benefits.

\section{Acknowledgements}

We thank the participants of the ANS \& EU-COST Biochar Symposium 2015 in Geisenheim for their active and lively discussions in section 6 "Biochar and GHG emissions". C. Kammann and H.-P. Schmidt thank Matthias Schröder for his work during the composting trials in Arbaz, Switzerland and later in the lab at Gießen University.

\section{Contribution}

CK developed the structure, wrote sections, contributed to sections and coordinated writing. JI and NH helped streamlining and finalizing the manuscript in addition to section contributions. All other authors contributed equally by reviewing the literature within their particular field of expertise and writing sections of the manuscript. (Therefore, all authors besides authors 1-3 are listed in alphabetical order.)

\section{Funding}

The COST Action TD1107, "Biochar for sustainable environmental management”, provided financial support for the EU-COST biochar symposium in 2015; the German BLE and FACCE-JPI funded the German participants of the "DesignerChar4Food" (D4F) project (CK: Project No. 2814ERA01A; NW-M: Project No. 2814ERA02A), the Spanish colleagues (JME and TFM) were funded by FACCE-CSA no 276610/MIT04-DESIGN-UPVASC and IT-932-16, and US colleagues (JN, JI and KS) were funded by The USDA-National Institute of Food and Agriculture (Project \# 2014-35615-21971), USDA-ARS CHARnet and GRACENet programs - D4F greatly stimulated discussions. We also gratefully acknowledge the following individual grants that enabled authors to contribute to this work: Claudia Kammann: German Science Foundation (DFG) grant [KA3442/1-1]; ML Cayuela thanks Fundación Séneca (Grant number 19281/PI/14); Nils Borchard was placed as integrated expert into the Center for International Forestry Research (CIFOR) by the Centre for International Migration and Development (CIM). CIM is a joint operation of the Deutsche Gesellschaft für Internationale Zusammenarbeit (GIZ) $\mathrm{GmbH}$ and the International Placement Services (ZAV) of the German Federal Employment Agency (BA).

\section{Disclosure statement}

None of the authors do have any competing financial, professional, or personal interests from other parties.

\section{References}

Alburquerque, J. A.; Sánchez-Monedero, M. A.; Roig, A.; Cayuela, M. L. 2015. High concentrations of polycyclic aromatic hydrocarbons (naphthalene, phenanthrene and 
pyrene) failed to explain biochar's capacity to reduce soil nitrous oxide emissions, Environmental Pollution 196: 72-77. https://doi.org/10.1016/j.envpol.2014.09.014

Ameloot, N.; Maenhout, P.; De Neve, S.; Sleutel, S. 2016. Biocharinduced $\mathrm{N}_{2} \mathrm{O}$ emission reductions after field incorporation in a loam soil, Geoderma 267: 10-16.

https://doi.org/10.1016/j.geoderma.2015.12.016

Amlinger, F.; Götz, B.; Dreher, P.; Geszti, J.; Weissteiner, C. 2003. Nitrogen in biowaste and yard waste compost: dynamics of mobilisation and availability - a review, European Journal of Soil Biology 39(3): 107-116. https://doi.org/10.1016/S1164-5563(03)00026-8

Amlinger, F.; Peyr, S.; Cuhls, C. 2008. Green house gas emissions from composting and mechanical biological treatment, Waste Management \& Research 26(1): 47-60.

https://doi.org/10.1177/0734242X07088432

Antal, M. J.; Grønli, M. 2003. The art, science, and technology of charcoal production, Industrial \& Engineering Chemistry Research 42(8): 1619-1640. https://doi.org/10.1021/ie0207919

Augustenborg, C. A.; Hepp, S.; Kammann, C.; Hagan, D.; Schmidt, O.; Müller, C. 2012. Biochar and earthworm effects on soil nitrous oxide and carbon dioxide emissions, Journal of Environmental Quality 41(4): 1203-1209. https://doi.org/10.2134/jeq2011.0119

Ball, P.; Mackenzie, M.; DeLuca, T.; Montana, W. 2010. Wildfire and charcoal enhance nitrification and ammonium-oxidizing bacterial abundance in dry montane forest soils, Journal of Environmental Quality 39(4): 1243-1253. https://doi.org/10.2134/jeq2009.0082

Bamminger, C.; Marschner, B.; Juschke, E. 2014. An incubation study on the stability and biological effects of pyrogenic and hydrothermal biochar in two soils, European Journal of Soil Science 65(1): 72-82. https://doi.org/10.1111/ejss.12074

Barker, J. C.; Zublena, J. P. 1995. Livestock manure nutrient assessment in North Carolina. Final Report. Raleigh, NC: North Carolina Agricultural Extension Service, North Carolina State University [online], [cited 28 December 2016]. Available from the Internet: https://pdfs.semanticscholar.org/3bab /336a20fc9d6710092faac2e3cbc8189495cc.pdf

Baronti, S.; Vaccari, F. P.; Miglietta, F.; Calzolari, C.; Lugato, E.; Orlandini, S.; Pini, R.; Zulian, C.; Genesio, L. 2014. Impact of biochar application on plant water relations in Vitis vinifera (L.), European Journal of Agronomy 53: 38-44. https://doi.org/10.1016/j.eja.2013.11.003

Bateman, E. J.; Baggs, E. M. 2005. Contributions of nitrification and denitrification to $\mathrm{N}_{2} \mathrm{O}$ emissions from soils at different water-filled pore space, Biology and Fertility of Soils 41(6): 379-388. https://doi.org/10.1007/s00374-005-0858-3

Bernal, M. P.; Alburquerque, J. A.; Moral, R. 2009. Composting of animal manures and chemical criteria for compost maturity assessment. A review, Bioresource Technology 100(22): 5444-5453. https://doi.org/10.1016/j.biortech.2008.11.027

Biederman, L. A.; Harpole, W. S. 2013. Biochar and its effects on plant productivity and nutrient cycling: a meta-analysis, $G C B$ Bioenergy 5(2): 202-214. https://doi.org/10.1111/gcbb.12037

Borchard, N.; Ladd, B.; Eschemann, S.; Hegenberg, D.; Moseler, B. M.; Amelung, W. 2014a. Black carbon and soil properties at historical charcoal production sites in Germany, Geoderma 232: 236-242.

https://doi.org/10.1016/j.geoderma.2014.05.007
Borchard, N.; Spokas, K.; Prost, K.; Siemens, J. 2014b. Greenhouse gas production in mixtures of soil with composted and noncomposted biochars ss governed by char-associated organic compounds, Journal of Environmental Quality 43(3): 971-979. https://doi.org/10.2134/jeq2013.07.0290

Brasseur, G. P.; Chatfield, R. B. 1991. The fate of biogenic trace gases in the atmosphere, in T. Sharkey, E. Holland. (Eds.). Trace gas emissions by plants. Cambridge MA: Academic Press. https://doi.org/10.1016/B978-0-12-639010-0.50006-6

Busch, D.; Kammann, C.; Grünhage, L.; Müller, C. 2012. Simple biotoxicity tests for evaluation of carbonaceous soil additives: establishment and reproducibility of four test procedures, Journal of Environmental Quality 41(4): 1023-1032. https://doi.org/10.2134/jeq2011.0122

Butterbach-Bahl, K.; Baggs, E. M.; Dannenmann, M.; Kiese, R.; Zechmeister-Boltenstern, S. 2013. Nitrous oxide emissions from soils: how well do we understand the processes and their controls?, Philosophical Transactions of the Royal Society B: Biological Sciences 368(1621): 20130122. https://doi.org/10.1098/rstb.2013.0122

Camps-Arbestain, M.; Amonette, J. E.; Singh, B.; Wang, T.; Schmidt, H. P. 2015. A biochar classification system and associated test methods, in J. Lehmann, J. Stephen (Eds.) Biochar for Environmental Management: Science, Technology and Implementation. $2^{\text {nd }}$ ed. London: Routledge.

Cantrell, K.; Ro, K.; Mahajan, D.; Anjom, M.; Hunt, P. G. 2007. Role of thermochemical conversion in livestock wasteto-energy treatments: obstacles and opportunities, Industrial \& Engineering Chemistry Research 46(26): 8918-8927. https://doi.org/10.1021/ie0616895

Cantrell, K. B.; Ducey, T.; Ro, K. S.; Hunt, P. G. 2008. Livestock waste-to-bioenergy generation opportunities, Bioresource Technology 99(17): 7941-7953. https://doi.org/10.1016/j.biortech.2008.02.061

Cantrell, K. B.; Hunt, P. G.; Uchimiya, M.; Novak, J. M.; Ro, K. S. 2012. Impact of pyrolysis temperature and manure source on physicochemical characteristics of biochar, Bioresource Technology 107: 419-428.

https://doi.org/10.1016/j.biortech.2011.11.084

Case, S. D. C.; Mcnamara, N. P.; Reay, D. S.; Whitaker, J. 2012. The effect of biochar addition on $\mathrm{N}_{2} \mathrm{O}$ and $\mathrm{CO}_{2}$ emissions from a sandy loam soil - The role of soil aeration, Soil Biology \& Biochemistry 51: 125-134. https://doi.org/10.1016/j.soilbio.2012.03.017

Castaldi, S.; Riondino, M.; Baronti, S.; Esposito, F. R.; Marzaioli, R.; Rutigliano, F. A.; Vaccari, F. P.; Miglietta, F. 2011. Impact of biochar application to a Mediterranean wheat crop on soil microbial activity and greenhouse gas fluxes, Chemosphere 85(9): 1464-1471.

https://doi.org/10.1016/j.chemosphere.2011.08.031

Castro, M. S.; Melillo, J. M.; Steudler, P. A.; Chapman, J. W. 1994. Soil moisture as a predictor of methane uptake by temperate forest soils, Canadian Journal of Forest Research 24(9): 1805-1810. https://doi.org/10.1139/x94-233

Castro, M. S.; Steudler, P. A.; Melillo, J. M.; Aber, J. D.; Bowden, R. D. 1995. Factors controlling atmospheric methane consumption by temperate forest soils, Global Biogeochemical Cycles 9(1): 1-10. https://doi.org/10.1029/94GB02651

Cato, M. P. 1935. On agiculture. London.

Cayuela, M. L.; Sanchez-Monedero, M. A.; Roig, A.; Hanley, K.; Enders, A.; Lehmann, J. 2013. Biochar and denitrification in 
soils: when, how much and why does biochar reduce $\mathrm{N}_{2} \mathrm{O}$ emissions?, Scientific Reports 3(1732).

Cayuela, M. L.; Van Zwieten, L.; Singh, B. P.; Jeffery, S.; Roig, A.; Sánchez-Monedero, M. A. 2014. Biochar's role in mitigating soil nitrous oxide emissions: a review and meta-analysis, Agriculture, Ecosystems \& Environment 191: 5-16. https://doi.org/10.1016/j.agee.2013.10.009

Chen, S.; Rotaru, A.-E.; Shrestha, P. M.; Malvankar, N. S.; Liu, F.; Fan, W.; Nevin, K. P.; Lovley, D. R. 2014. Promoting interspecies electron transfer with biochar, Scientific Reports 4: 5019. https://doi.org/10.1038/srep05019

Chen, C. R.; Phillips, I. R.; Condron, L. M.; Goloran, J.; Xu, Z. H.; Chan, K. Y. 2013. Impacts of greenwaste biochar on ammonia volatilisation from bauxite processing residue sand, Plant and Soil 367(1-2): 301-312. https://doi.org/10.1007/s11104-012-1468-0

Chen, Y.-X.; Huang, X.-D.; Han, Z.-Y.; Huang, X.; Hu, B.; Shi, D.-Z.; Wu, W.-X. 2010. Effects of bamboo charcoal and bamboo vinegar on nitrogen conservation and heavy metals immobility during pig manure composting, Chemosphere 78(9): 1177-1181.

https://doi.org/10.1016/j.chemosphere.2009.12.029

Choi, J.; Shinde, P.; Kwon, I.; Song, Y.; Chae, B. 2009. Effect of wood vinegar on the performance, nutrient digestibility and intestinal microflora in weanling pigs, Asian-Australian Journal of Animal Science 22(2): 267-274.

https://doi.org/10.5713/ajas.2009.80355

Christensen, T. R.; Johansson, T.; Åkerman, H. J.; Mastepanov, M.; Malmer, N.; Friborg, T.; Crill, P.; Svensson, B. H. 2004. Thawing sub-arctic permafrost: effects on vegetation and methane emissions, Geophysical Research Letters 31(L04501). https://doi.org/10.1029/2003gl018680

Clough, T. J.; Bertram, J. E.; Ray, J. L.; Condron, L. M.; O'callaghan, M.; Sherlock, R. R.; Wells, N. S. 2010. Unweathered wood biochar impact on nitrous oxide emissions from a bovine-urine-amended pasture soil, Soil Science Society of America Journal 74(3): 852-860.

https://doi.org/10.2136/sssaj2009.0185

Conrad, R. 1989. Control of methane production in terrestrial ecosystems, in M. Andreae, D. Schimel (Eds.). Exchange of trace gases between terrestrial ecosystems and the atmosphere. New York: Wiley.

Conrad, R. 1999. Contribution of hydrogen to methane production and control of hydrogen concentrations in methanogenic soils and sediments, FEMS Microbiology Ecology 28(3): 193-202. https://doi.org/10.1111/j.1574-6941.1999.tb00575.x

Conrad, R. 2007a. Microbial ecology of methanogens and methanotrophs, Advances in Agronomy 96: 1-63. https://doi.org/10.1016/S0065-2113(07)96005-8

Conrad, R. 2007b. Soil microbial communities and global climate change-methanotrophic and methanogenic communities as paradigms, in J. Van Elsas, J. Jansson, J. Trevors. (Eds.). Modern soil microbiology. $2^{\text {nd }}$ ed. Boca Raton: CRC Press.

Cornelissen, G.; Martinsen, V.; Shitumbanuma, V.; Alling, V.; Breedveld, G. D.; Rutherford, D. W.; Sparrevik, M.; Hale, S. E.; Obia, A.; Mulder, J. 2013. Biochar effect on maize yield and soil characteristics in five conservation farming sites in Zambia, Agronomy 3(2): 256-274.

https://doi.org/10.3390/agronomy3020256

Creamer, A. E.; Gao, B.; Zhang, M. 2014. Carbon dioxide capture using biochar produced from sugarcane bagasse and hickory wood, Chemical Engineering Journal 249: 174-179. https://doi.org/10.1016/j.cej.2014.03.105

Dalal, R.; Allen, D.; Livesley, S.; Richards, G. 2008. Magnitude and biophysical regulators of methane emission and consumption in the Australian agricultural, forest, and submerged landscapes: a review, Plant and Soil 309(1-2): 43-76. https://doi.org/10.1007/s11104-007-9446-7

Day, G. E. 1906. Swine: a book for students and farmers. Ithaca, NY: Cornell University Library. https://doi.org/10.5962/bhl.title.56553

DeLuca, T. H.; Mackenzie, M. D.; Gundale, M. J.; Holben, W. E. 2006. Wildfire-produced charcoal directly influences nitrogen cycling in ponderosa pine forests, Soil Science Society of America Journal 70(2): 448-453.

https://doi.org/10.2136/sssaj2005.0096

Demirbas, A. 2005. Potential applications of renewable energy sources, biomass combustion problems in boiler power systems and combustion related environmental issues, Progress in Energy and Combustion Science 31(2): 171-192. https://doi.org/10.1016/j.pecs.2005.02.002

Deng, Q.; Hui, D. F.; Wang, J. M.; Iwuozo, S.; Yu, C. L.; Jima, T.; Smart, D.; Reddy, C.; Dennis, S. 2015. Corn yield and soil nitrous oxide emission under different fertilizer and soil management: a three-year field experiment in Middle Tennessee, PLoS ONE 10(4): 14.

https://doi.org/10.1371/journal.pone.0125406

Dicke, C.; Andert, J.; Ammon, C.; Kern, J.; Meyer-Aurich, A.; Kaupenjohann, M. 2015. Effects of different biochars and digestate on $\mathrm{N}_{2} \mathrm{O}$ fluxes under field conditions, Science of the Total Environment 524-525: 310-318. https://doi. org/10.1016/j.scitotenv.2015.04.005

Dijkstra, J.; Oenema, O.; Bannink, A. 2011. Dietary strategies to reducing $\mathrm{N}$ excretion from cattle: implications for methane emissions, Current Opinion in Environmental Sustainability 3(5): 414-422. https://doi.org/10.1016/j.cosust.2011.07.008

Dlugokencky, E. J.; Steele, L. P.; Lang, P. M.; Masarie, K. A. 1994. The growth rate and distribution of atmospheric methane, Journal of Geophysical Research: Atmospheres 99(D8): 1702117043. https://doi.org/10.1029/94JD01245

Dong, D.; Feng, Q. B.; Mcgrouther, K.; Yang, M.; Wang, H. L.; Wu, W. X. 2015. Effects of biochar amendment on rice growth and nitrogen retention in a waterlogged paddy field, Journal of Soils and Sediments 15(1): 153-162. https://doi.org/10.1007/s11368-014-0984-3

Dunfield, P. F. 2007. 10 The soil methane sink, in D. S. Reay, C. N. Hewitt, K. A. Smith, J. Grace (Eds.). Greenhouse gas sinks. Wallingford and Cambridge MA: CABI. https://doi.org/10.1079/9781845931896.0152

EBC. 2012. European Biochar Foundation - European Biochar Certificate - Guidelines for a Sustainable Production of Biochar, Version 6.1 of June 19, 2015. European Biochar Foundation (EBC), Arbaz, Switzerland.

Energynumbers. 2005. Energy in natural processes and human consumption - Energy content of fuels [online], [cited 28 December 2016]. Available from Internet: http://www.ocean. washington.edu/courses/envir215/energynumbers.pdf

EU. 2011. Commission Regulation (EU) No 575/2011 of 16 June 2011 on the Catalogue of feed materials, Official Journal of the European Union L159, 54: 25-114.

Euronuclear. 2016. Fuel comparison - coal equivalent [online], [cited 28 December 2016]. Available from Internet: http:// www.euronuclear.org/info/encyclopedia/coalequivalent.htm. 
FAO. 2015. Statistical pocketbook - world food and agriculture. Food and Agriculture Organization of the United Nations, Rome.

FAO. 2016. Live animals [online]. Food and Agriculture Organization of the United Nations [cited 28 December 2016]. Available from Internet: http://www.fao.org/faostat/ en/?\#data/QA

Feng, Y.; Xu, Y.; Yu, Y.; Xie, Z.; Lin, X. 2012. Mechanisms of biochar decreasing methane emission from Chinese paddy soils, Soil Biology and Biochemistry 46: 80-88. https://doi.org/10.1016/j.soilbio.2011.11.016

Fornes, F.; Belda, R. M.; Lidón, A. 2015. Analysis of two biochars and one hydrochar from different feedstock: focus set on environmental, nutritional and horticultural considerations, Journal of Cleaner Production 86: 40-48. https://doi.org/10.1016/j.jclepro.2014.08.057

Fukumoto, Y.; Osada, T.; Hanajima, D.; Haga, K. 2003. Patterns and quantities of $\mathrm{NH}_{3}, \mathrm{~N}_{2} \mathrm{O}$ and $\mathrm{CH}_{4}$ emissions during swine manure composting without forced aeration - effect of compost pile scale, Bioresource Technology 89(2): 109-114. https://doi.org/10.1016/S0960-8524(03)00060-9

Galloway, J. N.; Townsend, A. R.; Erisman, J. W.; Bekunda, M.; Cai, Z.; Freney, J. R.; Martinelli, L. A.; Seitzinger, S. P.; Sutton, M. A. 2008. Transformation of the nitrogen cycle: Recent trends, questions, and potential solutions, Science 320(5878): 889-892. https://doi.org/10.1126/science.1136674

Gaskin, J.; Steiner, C.; Harris, K.; Das, K.; Bibens, B. 2008. Effect of low-temperature pyrolysis conditions on biochar for agricultural use, Transactions of the American Society of Agricultural and Biological Engineers 51(6): 2061-2069.

Genesio, L.; Miglietta, F.; Baronti, S.; Vaccari, F. P. 2015. Biochar increases vineyard productivity without affecting grape quality: Results from a four years field experiment in Tuscany, Agriculture, Ecosystems \& Environment 201: 20-25. https://doi.org/10.1016/j.agee.2014.11.021

Ghezzehei, T.; Sarkhot, D.; Berhe, A. 2014. Biochar can be used to recapture essential nutrients from dairy wastewater and improve soil quality, Solid Earth Discussions 6: 1101-1125. https://doi.org/10.5194/sed-6-1101-2014

Gollehon, N.; Caswell, M.; Ribaudo, M.; Kellogg, R.; Lander, C.; Letson, D. 2001. Confined animal production and manure nutrients [online]. Resource Economics Division, Economic Research Service, U.S. Department of Agriculture. Agriculture Information Bulletin No. 771 [cited 28 December 2016]. Available from the Internet: https://www.ers.usda.gov/webdocs/publications/aib771/17786_aib771_1_.pdf.

Gulledge, J.; Doyle, A. P.; Schimel, J. P. 1997. Different $\mathrm{NH}_{4}{ }^{+}$-inhibition patterns of soil $\mathrm{CH}_{4}$ consumption: a result of distinct $\mathrm{CH}_{4}$-oxidizer populations across sites?, Soil Biology and Biochemistry 29(1): 13-21.

https://doi.org/10.1016/S0038-0717(96)00265-9

Hackstein, J.; Stumm, C. K. 1994. Methane production in terrestrial arthropods, Proceedings of the National Academy of Sciences 91(12): 5441-5445.

https://doi.org/10.1073/pnas.91.12.5441

Hagemann, N.; Harter, J.; Kaldamukova, R.; Guzman-Bustamante, I.; Ruser, R.; Graeff, S.; Kappler, A.; Behrens, S. 2016. Does soil aging affect the $\mathrm{N}_{2} \mathrm{O}$ mitigation potential of biochar? A combined microcosm and field study, GCB Bioenergy 12390: 1-12.

Haider, G.; Steffens, D.; Müller, C.; Kammann, C. I. 2016. Standard extraction methods may underestimate nitrate stocks captured by field-aged biochar, Journal of Environmental Quality 45(4): 1196-1204.

https://doi.org/10.2134/jeq2015.10.0529

Hammer, T. J.; Fierer, N.; Hardwick, B.; Simojoki, A.; Slade, E.; Taponen, J.; Viljanen, H.; Roslin, T. 2016. Treating cattle with antibiotics affects greenhouse gas emissions, and microbiota in dung and dung beetles, Proceedings of the Royal Society $B$ : Biological Sciences 283(20160150).

https://doi.org/10.1098/rspb.2016.0150

Hansen, H. H.; Storm, I. M. L. D.; Sell, A. M. 2012. Effect of biochar on in vitro rumen methane production, Acta Agriculturae Scandinavica, Section A - Animal Science 62(4): 305-309.

Hansen, J.; Sato, M. 2016. Regional climate change and national responsibilities, Environmental Research Letters 11(3): 034009. https://doi.org/10.1088/1748-9326/11/3/034009

Hardy, B.; Cornelis, J. T.; Houben, D.; Lambert, R.; Dufey, J. 2016. The effect of pre-industrial charcoal kilns on chemical properties of forest soil of Wallonia, Belgium, European Journal of Soil Science 67(2): 206-216. https://doi.org/10.1111/ejss.12324

Hardy, B.; Cornelis, J. T.; Houben, D.; Leifeld, J.; Lambert, R.; Dufey, J. E. 2017. Evaluation of the long-term effect of biochar on properties of temperate agricultural soil at pre-industrial charcoal kiln sites in Wallonia, Belgium, European Journal of Soil Science 68(1): 80-89. https://doi.org/10.1111/ejss.12395

Harter, J.; Krause, H. M.; Schuettler, S.; Ruser, R.; Fromme, M.; Scholten, T.; Kappler, A.; Behrens, S. 2014. Linking $\mathrm{N}_{2} \mathrm{O}$ emissions from biochar-amended soil to the structure and function of the N-cycling microbial community, ISME Journal 8(3): 660-674. https://doi.org/10.1038/ismej.2013.160

Harter, J.; Weigold, P.; El-Hadidi, M.; Huson, D. H.; Kappler, A.; Behrens, S. 2016. Soil biochar amendment shapes the composition of $\mathrm{N}_{2} \mathrm{O}$-reducing microbial communities, Science of The Total Environment 562: 379-390. https://doi.org/10.1016/j.scitotenv.2016.03.220

Hiltbrunner, D.; Zimmermann, S.; Karbin, S.; Hagedorn, F.; Niklaus, P. A. 2012. Increasing soil methane sink along a 120year afforestation chronosequence is driven by soil moisture, Global Change Biology 18(12): 3664-3671. https://doi.org/10.1111/j.1365-2486.2012.02798.x

Hu, H.-W.; Chen, D.; He, J.-Z. 2015. Microbial regulation of terrestrial nitrous oxide formation: understanding the biological pathways for prediction of emission rates, FEMS Microbiology Reviews 39(5): 729-749. https://doi.org/10.1093/femsre/fuv021

Hua, L.; Chen, Y.; Wu, W. 2012. Impacts upon soil quality and plant growth of bamboo charcoal addition to composted sludge, Environmental Technology 33(1): 61-68. https://doi.org/10.1080/09593330.2010.549845

Hua, L.; Wu, W.; Liu, Y.; Mcbride, M. B.; Chen, Y. 2009. Reduction of nitrogen loss and $\mathrm{Cu}$ and $\mathrm{Zn}$ mobility during sludge composting with bamboo charcoal amendment, Environmental Science and Pollution Research 16(1): 1-9. https://doi.org/10.1007/s11356-008-0041-0

Hüppi, R.; Felber, R.; Neftel, A.; Six, J.; Leifeld, J. 2015. Effect of biochar and liming on soil nitrous oxide emissions from a temperate maize cropping system, SOIL 1(2): 707-717. https://doi.org/10.5194/soil-1-707-2015

Husson, O. 2013. Redox potential (Eh) and pH as drivers of soil/ plant/microorganism systems: a transdisciplinary overview 
pointing to integrative opportunities for agronomy, Plant and Soil 362(1-2): 389-417.

https://doi.org/10.1007/s11104-012-1429-7

Hütsch, B. W. 2001. Methane oxidation in non-flooded soils as affected by crop production - invited paper, European Journal of Agronomy 14(4): 237-260.

https://doi.org/10.1016/S1161-0301(01)00110-1

ISDA. 2016. The State of Idaho and USDA: Idaho OnePlan Nutrient Management Plan [online], [cited 28 December 2016]. Available from Internet: http://www.oneplan.org/NMPlan.asp

Islam, M. M.; Ahmed, S. T.; Kim, Y. J.; Mun, H. S.; Kim, Y. J.; Yang, C. J. 2014. Effect of sea tangle (Laminaria japonica) and charcoal supplementation as alternatives to antibiotics on growth performance and meat quality of ducks, AsianAustralasian Journal of Animal Sciences 27(2): 217-224. https://doi.org/10.5713/ajas.2013.13314

ISO 17512-1:2008. Soil quality - Avoidance test for determining the quality of soils and effects of chemicals on behaviour Part 1: Test with earthworms (Eisenia fetida and Eisenia andrei). International Organization for Standardization.

Jaffé, R.; Ding, Y.; Niggemann, J.; Vähätalo, A. V.; Stubbins, A.; Spencer, R. G.; Campbell, J.; Dittmar, T. 2013. Global charcoal mobilization from soils via dissolution and riverine transport to the oceans, Science 340(6130): 345-347. https://doi.org/10.1126/science.1231476

Jeffery, S.; Abalos, D.; Spokas, K.; Verheijen, F. G. A. 2015. Biochar effects on crop yield, in J. Lehmann, S. D. Joseph. (Eds.). Biochar for environmental management: science, technology and implementation. 2nd ed. Florence, KY, USA: Taylor and Francis.

Jeffery, S.; Verheijen, F. G.; Kammann, C.; Abalos, D. 2016. Biochar effects on methane emissions from soils: a meta-analysis, Soil Biology and Biochemistry 101: 251-258. https://doi.org/10.1016/j.soilbio.2016.07.021

Jia, J.; Li, B.; Chen, Z.; Xie, Z.; Xiong, Z. 2012. Effects of biochar application on vegetable production and emissions of $\mathrm{N}_{2} \mathrm{O}$ and $\mathrm{CH}_{4}$, Soil Science and Plant Nutrition 58(4): 503-509. https://doi.org/10.1080/00380768.2012.686436

Jia, X. Y.; Wang, M.; Yuan, W. Q.; Ju, X. T.; Yang, B. Z. 2016. the influence of biochar addition on chicken manure composting and associated methane and carbon dioxide emissions, Bioresources 11(2): 5255-5264.

https://doi.org/10.15376/biores.11.2.5255-5264

Jones, D. L.; Rousk, J.; Edwards-Jones, G.; Deluca, T. H.; Murphy, D. V. 2012. Biochar-mediated changes in soil quality and plant growth in a three year field trial, Soil Biology and Biochemistry 45: 113-124.

https://doi.org/10.1016/j.soilbio.2011.10.012

Joseph, S.; Graber, E. R.; Chia, C.; Munroe, P.; Donne, S.; Thomas, T.; Nielsen, S.; Marjo, C.; Rutlidge, H.; Pan, G. X.; Li, L.; Taylor, P.; Rawal, A.; Hook, J. 2013. Shifting paradigms: development of high-efficiency biochar fertilizers based on nano-structures and soluble components, Carbon Management 4(3): 323-343. https://doi.org/10.4155/cmt.13.23

Joseph, S.; Husson, O.; Graber, E. R.; Van Zwieten, L.; Taherymoosavi, S.; Thomas, T.; Nielsen, S.; Ye, J.; Pan, G.; Chia, C. 2015a. The electrochemical properties of biochars and how they affect soil redox properties and processes, Agronomy 5(3): 322-340. https://doi.org/10.3390/agronomy5030322

Joseph, S.; Pow, D.; Dawson, K.; Mitchell, D. R. G.; Rawal, A.; Hook, J.; Taherymoosavi, S.; Van Zwieten, L.; Rust, J.;
Donne, S.; Munroe, P.; Pace, B.; Graber, E.; Thomas, T.; Nielsen, S.; Ye, J.; Lin, Y.; Pan, G.; Li, L.; Solaiman, Z. M. 2015b. Feeding biochar to cows: an innovative solution for improving soil fertility and farm productivity, Pedosphere 25(5): 666-679.

https://doi.org/10.1016/S1002-0160(15)30047-3

Jung, M.-Y.; Well, R.; Min, D.; Giesemann, A.; Park, S.-J.; Kim, J.-G.; Kim, S.-J.; Rhee, S.-K. 2014. Isotopic signatures of $\mathrm{N}_{2} \mathrm{O}$ produced by ammonia-oxidizing archaea from soils, ISME Journal 8(5): 1115-1125.

https://doi.org/10.1038/ismej.2013.205

Juutinen, S.; Alm, J.; Larmola, T.; Huttunen, J. T.; Morero, M.; Saarnio, S.; Martikainen, P. J.; Silvola, J. 2003. Methane $\left(\mathrm{CH}_{4}\right)$ release from littoral wetlands of boreal lakes during an extended flooding period, Global Change Biology 9(3): 413-424. https://doi.org/10.1046/j.1365-2486.2003.00595.x

Kalachniuk, H. I.; Marounek, M.; Kalachniuk, L. H.; Savka, O. H. 1994. Rumen bacterial metabolism as affected by extracellular redox potential, Ukrainskii biokhimicheskii zhurnal (1978) 66(1): 30-40.

Kammann, C.; Hepp, S.; Lenhart, K.; Müller, C. 2009. Stimulation of methane consumption by endogenous $\mathrm{CH}_{4}$ production in aerobic grassland soil, Soil Biology and Biochemistry 41(3): 622-629. https://doi.org/10.1016/j.soilbio.2008.12.025

Kammann, C.; Ratering, S.; Eckhard, C.; Muller, C. 2012. Biochar and hydrochar effects on greenhouse gas (carbon dioxide, nitrous oxide, and methane) fluxes from soils, Journal of Environmental Quality 41(4): 1052-1066. https://doi.org/10.2134/jeq2011.0132

Kammann, C. I.; Glaser, B.; Schmidt, H.-P. 2016. Combining biochar and organic amendments, in S. Shackley, G. Ruysschaert, K. Zwart, B. Glaser (Eds.). Biochar in European soils and agriculture: science and practice. London: Routledge.

Kammann, C. I.; Schmidt, H. P.; Messerschmidt, N.; Linsel, S.; Steffens, D.; Muller, C.; Koyro, H. W.; Conte, P.; Stephen, J. 2015. Plant growth improvement mediated by nitrate capture in co-composted biochar, Scientific Reports 5(11080). https://doi.org/10.1038/srep11080

Kappler, A.; Wuestner, M. L.; Ruecker, A.; Harter, J.; Halama, M.; Behrens, S. 2014. Biochar as an electron shuttle between bacteria and Fe(III) minerals, Environmental Science \& Technology Letters 1(8): 339-344. https://doi.org/10.1021/ez5002209

Karhu, K.; Mattila, T.; Bergström, I.; Regina, K. 2011. Biochar addition to agricultural soil increased $\mathrm{CH}_{4}$ uptake and water holding capacity - Results from a short-term pilot field study, Agriculture, Ecosystems \& Environment 140(1-2): 309-313. https://doi.org/10.1016/j.agee.2010.12.005

Kellogg, R. L.; Lander, C. H.; Moffitt, D. C.; Gollehon, N. 2000. Manure nutrients relative to the capacity of cropland and pastureland to assimilate nutrients: spatial and temporal trends for the United States, Proceedings of the Water Environment Federation 2000(16): 18-157. https://doi.org/10.2175/193864700784994812

Kern, J.; Hellebrand, H. J.; Gömmel, M.; Ammon, C.; Berg, W. 2012. Effects of climatic factors and soil management on the methane flux in soils from annual and perennial energy crops, Biology and Fertility of Soils 48(1): 1-8. https://doi.org/10.1007/s00374-011-0603-Z

Kern, J.; Tammeorg, P.; Shanskiy, M.; Sakrabani, R.; Knicker, H.; Kammann, C. I.; Tuhkanen, E.-M.; Smidt, G.; Prasad, M.; Kari, T.; Sohi, S.; Gascó, G.; Steiner, C.; Glaser, G. 2017. 
Synergistic use of peat and charred material in growing media an option to reduce the pressure on peatlands?, Journal of Environmental Engineering and Landscape Management (this issue).

Khan, S.; Chao, C.; Waqas, M.; Arp, H. P.; Zhu, Y. G. 2013a. Sewage sludge biochar influence upon rice (Oryza sativa L) yield, metal bioaccumulation and greenhouse gas emissions from acidic paddy soil, Environmental Science \& Technology 47: 8624-8632. https://doi.org/10.1021/es400554x

Khan, S.; Chao, C.; Waqas, M.; Arp, H. P. H.; Zhu, Y. G. 2013b. Sewage sludge biochar influence upon rice (Oryza sativa L) yield, metal bioaccumulation and greenhouse gas emissions from acidic paddy soil, Environmental Science \& Technology 47(15): 8624-8632. https://doi.org/10.1021/es400554x

Kluepfel, L.; Keiluweit, M.; Kleber, M.; Sander, M. 2014. Redox properties of plant biomass-derived black carbon (biochar), Environmental Science \& Technology 48(10): 5601-5611. https://doi.org/10.1021/es500906d

Kollah, B.; Dubey, G.; Parasai, P.; Saha, J. K.; Gangil, S.; Mohanty, S. R. 2015. Interactive effect of biochar size and organic amendments on methane consumption in a tropical vertisol, Soil Use and Management 31(1): 52-59.

https://doi.org/10.1111/sum.12168

Kömpf, K. 2013. Consequences of aging of pyrogenous biochar regarding the potential to reduce nitrous oxide from soil: Bachelor Thesis. Justus-Liebig-University, Giessen. 61 p. (in German).

Konuma, H. 2016. Status of world food security and its future outlook, and role of agricultural research and education, Journal of Developments in Sustainable Agriculture 10(2): 69-75.

Kool, D. M.; Dolfing, J.; Wrage, N.; Van Groenigen, J. W. 2011a. Nitrifier denitrification as a distinct and significant source of nitrous oxide from soil, Soil Biology and Biochemistry 43(1): 174-178. https://doi.org/10.1016/j.soilbio.2010.09.030

Kool, D. M.; Van Groenigen, J. W. Wrage, N. 2011b. Source determination of nitrous oxide based on nitrogen and oxygen isotope tracing: dealing with oxygen exchange, Chapter 6, in G. K. Martin, Y. S. Lisa. (Eds.). Methods in enzymology. Academic Press.

https://doi.org/10.1016/b978-0-12-386489-5.00006-3

Koven, C. D.; Ringeval, B.; Friedlingstein, P.; Ciais, P.; Cadule, P.; Khvorostyanov, D.; Krinner, G.; Tarnocai, C. 2011. Permafrost carbon-climate feedbacks accelerate global warming, Proceedings of the National Academy of Sciences 108(36): 14769-14774. https://doi.org/10.1073/pnas.1103910108

Kozlowski, J. A.; Price, J.; Stein, L. Y. 2014. Revision of $\mathrm{N}_{2} \mathrm{O}-$ Producing pathways in the ammonia-oxidizing bacterium Nitrosomonas europaea ATCC 19718, Applied and Environmental Microbiology 80(16): 4930-4935.

https://doi.org/10.1128/AEM.01061-14

Laird, D. A.; Brown, R. C.; Amonette, J. E.; Lehmann, J. 2009. Review of the pyrolysis platform for coproducing bio-oil and biochar, Biofuels, Bioproducts and Biorefining 3(5): 547-562. https://doi.org/10.1002/bbb.169

Lal, R. 2014. Desertification and soil erosion, in B. Freedman (Ed.). Global environmental change. Dordrecht: Springer Netherlands. https://doi.org/10.1007/978-94-007-5784-4_7

Laughlin, R. J.; Stevens, R. J. 2002. Evidence for fungal dominance of denitrification and codenitrification in a grassland Soil, Soil Science Society of America Journal 66(5): 1540-1548. https://doi.org/10.2136/sssaj2002.1540
Lee, J. W.; Hawkins, B.; Li, X.; Day, D. M. 2013. Biochar fertilizer for soil amendment and carbon sequestration, in J. W. Lee (Ed.). Advanced biofuels and bioproducts. New York, NY: Springer New York. https://doi.org/10.1007/978-1-4614-3348-4_6

Lehmann, J.; Abiven, S.; Kleber, M.; Pan, G.; Singh, B. P.; Sohi, S. P.; Zimmerman, A. R.; Lehmann, J.; Joseph, S. 2015. Persistence of biochar in soil, in J. Lehmann, J. Stephen (Eds.). Biochar for environmental management: science, technology and implementation. $2^{\text {nd }}$ ed. London: Routledge.

Leng, R. A.; Inthapanya, S.; Preston, T. R. 2012a. Biochar lowers net methane production from rumen fluid in vitro. Livestock Research for Rural Development 24(103) [online], [cited 28 December 2016]. Available from Internet: http://www.lrrd. org/lrrd24/6/sang24103.htm

Leng, R.; Preston, T.; Inthapanya, S. 2012b. Biochar reduces enteric methane and improves growth and feed conversion in local "Yellow" cattle fed cassava root chips and fresh cassava foliage, Livestock Research for Rural Development 24(11) [online], [cited 28 December 2016]. Available from Internet: http://www.lrrd.org/lrrd24/11/leng24199.htm

Leng, R. A.; Inthapanya, S.; Preston, T. R. 2013. All biochars are not equal in lowering methane production in in vitro rumen incubations, Livestock Research for Rural Development 25(6) [online], [cited 28 December 2016]. Available from Internet: http://www.lrrd.org/lrrd25/6/leng25106.htm

Lewicka-Szczebak, D.; Dyckmans, J.; Kaiser, J.; Marca, A.; Augustin, J.; Well, R. 2016. Oxygen isotope fractionation during $\mathrm{N}_{2} \mathrm{O}$ production by soil denitrification, Biogeosciences 13: 1129-1144. https://doi.org/10.5194/bg-13-1129-2016

Li, B.; Fan, C.; Zhang, H.; Chen, Z.; Sun, L.; Xiong, Z. 2015. Combined effects of nitrogen fertilization and biochar on the net global warming potential, greenhouse gas intensity and net ecosystem economic budget in intensive vegetable agriculture in southeastern China, Atmospheric Environment 100: 10-19. https://doi.org/10.1016/j.atmosenv.2014.10.034

Li, S. Q.; Song, L. N.; Jin, Y. G.; Liu, S. W.; Shen, Q. R.; Zou, J. W. 2016. Linking $\mathrm{N}_{2} \mathrm{O}$ emission from biochar-amended composting process to the abundance of denitrify (nirK and nosZ) bacteria community, Amb Express 6(37): 1-9. https://doi.org/10.1186/s13568-016-0208-x

Liiri, M.; Setälä, H.; Haimi, J.; Pennanen, T.; Fritze, H. 2002. Soil processes are not influenced by the functional complexity of soil decomposer food webs under disturbance, Soil Biology and Biochemistry 34(7): 1009-1020.

https://doi.org/10.1016/S0038-0717(02)00034-2

Lin, X.; Spokas, K. A.; Venterea, R. T.; Zhang, R.; Baker, J. M.; Feyereisen, G. W. 2014. Assessing microbial contributions to $\mathrm{N}_{2} \mathrm{O}$ impacts following biochar additions, Agronomy 4(4): 478-496. https://doi.org/10.3390/agronomy4040478

Lin, X.; Xie, Z.; Zheng, J.; Liu, Q.; Bei, Q. Zhu, J. 2015. Effects of biochar application on greenhouse gas emissions, carbon sequestration and crop growth in coastal saline soil, European Journal of Soil Science 66(2): 329-338.

https://doi.org/10.1111/ejss.12225

Liu, F.; Rotaru, A.-E.; Shrestha, P. M.; Malvankar, N. S.; Nevin, K. P.; Lovley, D. R. 2012. Promoting direct interspecies electron transfer with activated carbon, Energy \& Environmental Science 5(10): 8982-8989. https://doi.org/10.1039/c2ee22459c

Liu, L.; Shen, G.; Sun, M.; Cao, X.; Shang, G.; Chen, P. 2014. Effect of biochar on nitrous oxide emission and its potential 
mechanisms, Journal of the Air \& Waste Management Association 64: 894-902.

https://doi.org/10.1080/10962247.2014.899937

López-Cano, I.; Roig, A.; Cayuela, M. L.; Alburquerque, J. A.; Sánchez-Monedero, M. A. 2016. Biochar improves N cycling during composting of olive mill wastes and sheep manure, Waste Management 49: 553-559.

https://doi.org/10.1016/j.wasman.2015.12.031

Lovley, D. R.; Phillips, E. J. 1987. Competitive mechanisms for inhibition of sulfate reduction and methane production in the zone of ferric iron reduction in sediments, Applied and Environmental Microbiology 53(11): 2636-2641.

Lv, D.; Xu, M.; Liu, X.; Zhan, Z.; Li, Z.; Yao, H. 2010. Effect of cellulose, lignin, alkali and alkaline earth metallic species on biomass pyrolysis and gasification, Fuel Processing Technology 91(8): 903-909. https://doi.org/10.1016/j.fuproc.2009.09.014

Malghani, S.; Gleixner, G.; Trumbore, S. E. 2013. Chars produced by slow pyrolysis and hydrothermal carbonization vary in carbon sequestration potential and greenhouse gases emissions, Soil Biology and Biochemistry 62: 137-146. https://doi.org/10.1016/j.soilbio.2013.03.013

Malinska, K.; Zabochnicka-Swiatek, M.; Dach, J. 2014. Effects of biochar amendment on ammonia emission during composting of sewage sludge, Ecological Engineering 71: 474-478. https://doi.org/10.1016/j.ecoleng.2014.07.012

Marras, S.; Masia, S.; Duce, P.; Spano, D.; Sirca, C. 2015. Carbon footprint assessment on a mature vineyard, Agricultural and Forest Meteorology 214: 350-356.

https://doi.org/10.1016/j.agrformet.2015.08.270

MDE. 2016. AFO (CAFO/MAFO) information page [online]. Maryland Department of the Environment [cited 28 December 2016]. Available from the Internet: http://www.mde.state. md.us/programs/Land/RecyclingandOperationsprogram/ AFO/Pages/index.aspx

Megonigal, J.; Whalen, S. C.; Tissue, D.; Bovard, B.; Allen, A.; Albert, D. 1999. A plant-soil-atmosphere microcosm for tracing radiocarbon from photosynthesis through methanogenesis, Soil Science Society of America Journal 63(3): 665-671. https://doi.org/10.2136/sssaj1999.03615995006300030033x

Min, J.; Lu, K.; Sun, H.; Xia, L.; Zhang, H.; Shi, W. 2016. Global warming potential in an intensive vegetable cropping system as affected by crop rotation and nitrogen rate, CLEAN - Soil, Air, Water 44(7): 766-774.

https://doi.org/10.1002/clen.201400785

Mochidzuki, K.; Soutric, F.; Tadokoro, K.; Antal, M. J.; Tóth, M.; Zelei, B.; Várhegyi, G. 2003. Electrical and physical properties of carbonized charcoals, Industrial \& Engineering Chemistry Research 42(21): 5140-5151. https://doi.org/10.1021/ie030358e

Myhre, G.; Shindell, D.; Bréon, F. M.; Collins, W.; Fuglestvedt, J.; Huang, J.; Koch, D.; Lamarque, J. F.; Lee, D.; Mendoza, B.; Nakajima, T.; Robock, A.; Stephens, G.; Takemura, T.; Zhang, H. 2013. Anthropogenic and natural radiative forcing, in T. F. Stocker, D. Qin, G. K. Plattner, M. Tignor, S. K. Allen, J. Boschung, A. Nauels, Y. Xia, V. Bex, P. M. Midgley (Eds.) Climate change 2013: the physical science basis. Contribution of working group I to the fifth assessment report of the intergovernmental panel on climate change. Cambridge and New York, NY: Cambridge University Press.

Naka, K.; Watarai, S.; Tana; Inoue, K.; Kodama, Y.; Oguma, K.; Yasuda, T.; Kodama, H. 2001. Adsorption effect of activated charcoal on enterohemorrhagic Escherichia coli, Journal of Veterinary Medical Science 63(3): 281-285.

https://doi.org/10.1292/jvms.63.281

Nelissen, V.; Rütting, T.; Huygens, D.; Staelens, J.; Ruysschaert, G.; Boeckx, P. 2012. Maize biochars accelerate short-term soil nitrogen dynamics in a loamy sand soil, Soil Biology \& Biochemistry 55: 20-27. https://doi.org/10.1016/j.soilbio.2012.05.019

Nelissen, V.; Saha, B. K.; Ruysschaert, G.; Boeckx, P. 2014. Effect of different biochar and fertilizer types on $\mathrm{N}_{2} \mathrm{O}$ and $\mathrm{NO}$ emissions, Soil Biology \& Biochemistry 70: 244-255. https://doi.org/10.1016/j.soilbio.2013.12.026

Nguyen, D. H.; Biala, J.; Grace, P. R.; Scheer, C.; Rowlings, D. W. 2014. Greenhouse gas emissions from sub-tropical agricultural soils after addition of organic by-products, Springerplus 3(491): 14. https://doi.org/10.1186/2193-1801-3-491

Novak, J.; Cantrell, K.; Watts, D. 2013. Compositional and thermal evaluation of lignocellulosic and poultry litter chars via high and low temperature pyrolysis, Bioenergy Research 6(1): 114-130. https://doi.org/10.1007/s12155-012-9228-9

O’Toole, A.; Andersson, D.; Gerlach, A.; Glaser, B.; Kammann, C. I.; Kern, J.; Kuoppamäki, K.; Mumme, J.; Schmidt, H. P.; Schulze, M.; Srocke, F.; Stenrød, M.; Stenström, J. 2016. Current and future applications for biochar, in S. Shackley, G. Ruysschaert, K. Zwart, B. Glaser (Eds.). Biochar in European soils and agriculture: science and practice. London: Routledge.

Obia, A.; Cornelissen, G.; Mulder, J.; Dörsch, P. 2015. Effect of soil $\mathrm{pH}$ increase by biochar on $\mathrm{NO}, \mathrm{N}_{2} \mathrm{O}$ and $\mathrm{N}_{2}$ production during denitrification in acid soils, PLoS ONE 10(9): e0138781. https://doi.org/10.1371/journal.pone.0138781

Obia, A.; Mulder, J.; Martinsen, V.; Cornelissen, G.; Børresen, T. 2016. In situ effects of biochar on aggregation, water retention and porosity in light-textured tropical soils, Soil and Tillage Research 155: 35-44. https://doi.org/10.1016/j.still.2015.08.002

Ojima, D. S.; Valentine, D. W.; Mosier, A. R.; Parton, W. J.; Schimel, D. S. 1993. Effect of land use change on methane oxidation in temperate forest and grassland soils, Chemosphere 26(1): 675-685. https://doi.org/10.1016/0045-6535(93)90452-B

Oremland, R. S. 1988. Biogeochemistry of methanogenic bacteria, in A. J. B. Zehnder (Ed.). Biology of anaerobic microorganisms. New York: John Wiley and Sons.

Perez-Garcia, O.; Villas-Boas, S. G.; Swift, S.; Chandran, K.; Singhal, N. 2014. Clarifying the regulation of $\mathrm{NO} / \mathrm{N}_{2} \mathrm{O}$ production in Nitrosomonas europaea during anoxic-oxic transition via flux balance analysis of a metabolic network model, Water Research 60: 267-277. https://doi.org/10.1016/j.watres.2014.04.049

Powlson, D.; Goulding, K.; Willison, T. Webster, C.; Hütsch, B. 1997. The effect of agriculture on methane oxidation in soil, Nutrient Cycling in Agroecosystems 49(1-3): 59-70. https://doi.org/10.1023/A:1009704226554

Prévoteau, A.; Ronsse, F.; Cid, I.; Boeckx, P.; Rabaey, K. 2016. The electron donating capacity of biochar is dramatically underestimated, Scientific Reports 6(32870). https://doi.org/10.1038/srep32870

Prommer, J.; Wanek, W.; Hofhansl, F.; Trojan, D.; Offre, P.; Urich, T.; Schleper, C.; Sassmann, S.; Kitzler, B.; Soja, G.; Hood-Nowotny, R. C. 2014. Biochar decelerates soil organic nitrogen cycling but stimulates soil nitrification in a temperate arable field trial, PLOS ONE 9(1): e86388. https://doi.org/10.1371/journal.pone.0086388 
Prost, K.; Borchard, N.; Siemens, J.; Kautz, T.; Séquaris, J.-M.; Möller, A.; Amelung, W. 2013. Biochar affected by composting with farmyard manure, Journal of Environmental Quality 42(1): 164-172. https://doi.org/10.2134/jeq2012.0064

PSAC. 1905. Annual report of the Pennsylvania Agricultural Experiment Station. State College, PA, Pennsylvania State Agricultural College.

Qian, L.; Chen, L.; Joseph, S.; Pan, G.; Li, L.; Zheng, J.; Zhang, X.; Zheng, J.; Yu, X.; Wang, J. 2014. Biochar compound fertilizer as an option to reach high productivity but low carbon intensity in rice agriculture of China, Carbon Management 5(2): 145-154. https://doi.org/10.1080/17583004.2014.912866

Quin, P.; Joseph, S.; Husson, O.; Donne, S.; Mitchell, D.; Munroe, P.; Phelan, D.; Cowie, A.; Van Zwieten, L. 2015. Lowering $\mathrm{N}_{2} \mathrm{O}$ emissions from soils using eucalypt biochar: the importance of redox reactions, Scientific Reports 5(16773). https://doi.org/10.1038/srep16773

Ravishankara, A. R.; Daniel, J. S.; Portmann, R. W. 2009. Nitrous oxide $\left(\mathrm{N}_{2} \mathrm{O}\right)$ : The dominant ozone-depleting substance emitted in the $21^{\text {st }}$ century, Science 326(5949): 123-125. https://doi.org/10.1126/science.1176985

Reddy, K. R.; Yargicoglu, E. N.; Yue, D.; Yaghoubi, P. 2014. Enhanced microbial methane oxidation in landfill cover soil amended with biochar, Journal of Geotechnical and Geoenvironmental Engineering 140(9): 04014047. https://doi.org/10.1061/(ASCE)GT.1943-5606.0001148

Rohe, L.; Anderson, T.-H.; Braker, G.; Flessa, H.; Giesemann, A.; Lewicka-Szczebak, D.; Wrage-Mönnig, N.; Well, R. 2014. Dual isotope and isotopomer signatures of nitrous oxide from fungal denitrification - a pure culture study, Rapid Communications in Mass Spectrometry 28(17): 1893-1903. https://doi.org/10.1002/rcm.6975

Rondon, M.; Ramirez, J.; Lehmann, J. 2005. Greenhouse gas emissions decrease with charcoal additions to tropical soils, in Proceedings of the $3^{\text {rd }}$ USDA Symposium on Greenhouse Gases and Carbon Sequestration, 2005, Baltimore, USA.

Rulli, M. C.; Saviori, A.; D’odorico, P. 2013. Global land and water grabbing, Proceedings of the National Academy of Sciences 110(3): 892-897. https://doi.org/10.1073/pnas.1213163110

Ruser, R.; Schilling, R.; Steindl, H.; Flessa, H.; Beese, F. 1998. Soil compaction and fertilization effects on nitrous oxide and methane fluxes in potato fields, Soil Science Society of America Journal 62(6): 1587-1595.

https://doi.org/10.2136/sssaj1998.03615995006200060016x

Rütting, T.; Müller, C. 2007. ${ }^{15} \mathrm{~N}$ tracing models with a Monte Carlo optimization procedure provide new insights on gross $\mathrm{N}$ transformations in soils, Soil Biology and Biochemistry 39(9): 2351-2361.

https://doi.org/10.1016/j.soilbio.2007.04.006

Ruysschaert, G.; Nelissen, V.; Postma, R.; Bruun, E.; O’toole, A.; Hammond, J.; Rödger, J.-M.; Ylander, L.; Kihlberg, T.; Zwart, K.; Hauggaard-Nielsen, H.; Shackley, S. 2016. Field applications of pure biochar in the North Sea region and across Europe, in S. Shackley, G. Ruysschaert, K. Zwart, B. Glaser (Eds.). Biochar in European soils and agriculture: science and practice. London: Routledge.

Saarnio, S. 2016. Impacts of biochar amendment on greenhouse gas emissions from agricultural soils, Chapter 9 in M. Guo, Z. He, M. Uchimiya (Eds.). Agricultural and environmental applications of biochar: advances and barriers. 63 ed. Madison, WI.: Soil Science Society of America.

https://doi.org/10.2136/sssaspecpub63.2014.0045
Saarnio, S.; Alm, J.; Silvola, J.; Lohila, A.; Nykänen, H.; Martikainen, P. J. 1997. Seasonal variation in $\mathrm{CH}_{4}$ emissions and production and oxidation potentials at microsites on an oligotrophic pine fen, Oecologia 110(3): 414-422. https://doi.org/10.1007/s004420050176

Saarnio, S.; Heimonen, K.; Kettunen, R. 2013. Biochar addition indirectly affects $\mathrm{N}_{2} \mathrm{O}$ emissions via soil moisture and plant N uptake, Soil Biology \& Biochemistry 58: 99-106. https://doi.org/10.1016/j.soilbio.2012.10.035

Saarnio, S.; Winiwarter, W.; Leitao, J. 2009. Methane release from wetlands and watercourses in Europe, Atmospheric Environment 43(7): 1421-1429. https://doi.org/10.1016/j.atmosenv.2008.04.007

Saarnio, S.; Wittenmayer, L.; Merbach, W. 2004. Rhizospheric exudation of Eriophorum vaginatum L. - potential link to methanogenesis, Plant and Soil 267(1-2): 343-355. https://doi.org/10.1007/s11104-005-0140-3

Sadasivam, B. Y.; Reddy, K. R. 2015. Adsorption and transport of methane in landfill cover soil amended with waste-wood biochars, Journal of Environmental Management 158: 11-23. https://doi.org/10.1016/j.jenvman.2015.04.032

Sánchez-García, M.; Alburquerque, J. A.; Sánchez-Monedero, M. A.; Roig, A.; Cayuela, M. L. 2015. Biochar accelerates organic matter degradation and enhances $\mathrm{N}$ mineralisation during composting of poultry manure without a relevant impact on gas emissions, Bioresource Technology 192: 272-279. https://doi.org/10.1016/j.biortech.2015.05.003

Sánchez-García, M.; Roig, A.; Sanchez-Monedero, M. A.; Cayuela, M. L. 2014. Biochar increases soil $\mathrm{N}_{2} \mathrm{O}$ emissions produced by nitrification-mediated pathways, Frontiers in Environmental Science 2(25): 1-10.

Sánchez-García, M.; Sánchez-Monedero, M. A.; Roig, A.; LópezCano, I.; Moreno, B.; Benitez, E.; Cayuela, M. L. 2016. Compost vs biochar amendment: a two-year field study evaluating soil $\mathrm{C}$ build-up and $\mathrm{N}$ dynamics in an organically managed olive crop, Plant and Soil 408(1): 1-14. https://doi.org/10.1007/s11104-016-2794-4

Saunois, M.; Jackson, R. B.; Bousquet, P.; Poulter, B.; Canadell, J. G. 2016. The growing role of methane in anthropogenic climate change, Environmental Research Letters 11(12): 120207. https://doi.org/10.1088/1748-9326/11/12/120207

Savage, E. S. 1917. Feeding dairy cattle, Holstein-Friesian World $1(47)$.

Scheer, C.; Grace, P. R.; Rowlings, D. W.; Kimber, S.; Van Zwieten, L. 2011. Effect of biochar amendment on the soil-atmosphere exchange of greenhouse gases from an intensive subtropical pasture in northern New South Wales, Australia, Plant and Soil 345(1-2): 47-58. https://doi.org/10.1007/s11104-011-0759-1

Schimmelpfennig, S.; Müller, C.; Grünhage, L.; Koch, C.; Kammann, C. 2014. Biochar, hydrochar and uncarbonized feedstock application to permanent grassland - Effects on greenhouse gas emissions and plant growth, Agriculture, Ecosystems \& Environment 191: 39-52. https://doi.org/10.1016/j.agee.2014.03.027

Schmidt, H.-P.; Pandit, B.; Martinsen, V.; Cornelissen, G.; Conte, P.; Kammann, C. 2015. Fourfold increase in pumpkin yield in response to low-dosage root zone application of urine-enhanced biochar to a fertile tropical soil, Agriculture 5(3): 23. https://doi.org/10.3390/agriculture5030723

Schmidt, H. P.; Kammann, C.; Niggli, C.; Evangelou, M. W. H.; Mackie, K. A.; Abiven, S. 2014. Biochar and biochar-compost 
as soil amendments to a vineyard soil: Influences on plant growth, nutrient uptake, plant health and grape quality, Agriculture Ecosystems \& Environment 191: 117-123.

https://doi.org/10.1016/j.agee.2014.04.001

Schmidt, H. P.; Kammann, C. I.; Gerlach, A.; Gerlach, H. 2016. Der Einsatz von Pflanzenkohle in der Tierfütterung, IthakaJournal 95: 364-394.

Schnell, S.; King, G. M. 1995. Stability of methane oxidation capacity to variations in methane and nutrient concentrations, FEMS Microbiology Ecology 17(4): 285-294.

https://doi.org/10.1111/j.1574-6941.1995.tb00153.x

Seiler, W.; Conrad, R.; Scharffe, D. 1984. Field studies of methane emission from termite nests into the atmosphere and measurements of methane uptake by tropical soils, Journal of Atmospheric Chemistry 1(2): 171-186. https://doi.org/10.1007/BF00053839

Shaw, L. J.; Nicol, G. W.; Smith, Z.; Fear, J.; Prosser, J. I.; Baggs, E. M. 2006. Nitrosospira spp. can produce nitrous oxide via a nitrifier denitrification pathway, Environmental Microbiology 8(2): 214-222.

https://doi.org/10.1111/j.1462-2920.2005.00882.x

Shi, L.; Dong, H.; Reguera, G.; Beyenal, H.; Lu, A.; Liu, J.; Yu, H.-Q.; Fredrickson, J. K. 2016. Extracellular electron transfer mechanisms between microorganisms and minerals, Nature Reviews Microbiology 14: 651-662.

https://doi.org/10.1038/nrmicro.2016.93

Snider, D.; Thompson, K.; Wagner-Riddle, C.; Spoelstra, J.; Dunfield, K. 2015. Molecular techniques and stable isotope ratios at natural abundance give complementary inferences about $\mathrm{N}_{2} \mathrm{O}$ production pathways in an agricultural soil following a rainfall event, Soil Biology and Biochemistry 88: 197-213. https://doi.org/10.1016/j.soilbio.2015.05.021

Solomon, D.; Lehmann, J.; Fraser, J. A.; Leach, M.; Amanor, K.; Frausin, V.; Kristiansen, S. M.; Millimouno, D.; Fairhead, J. 2016. Indigenous African soil enrichment as a climatesmart sustainable agriculture alternative, Frontiers in Ecology and the Environment 14(2): 71-76. https://doi.org/10.1002/fee.1226

Song, X.; Pan, G.; Zhang, C.; Zhang, L.; Wang, H. 2016. Effects of biochar application on fluxes of three biogenic greenhouse gases: a meta-analysis, Ecosystem Health and Sustainability 2(2): e01202. https://doi.org/10.1002/ehs2.1202

Sonoki, T.; Furukawa, T.; Jindo, K.; Suto, K.; Aoyama, M.; Sanchez-Monedero, M. A. 2013. Influence of biochar addition on methane metabolism during thermophilic phase of composting, Journal of Basic Microbiology 53(7): 617-621. https://doi.org/10.1002/jobm.201200096

Sonoki, T.; Furukawa, T.; Mizumoto, H.; Jindo, K.; Aoyama, M.; Sanchez-Monedero, M. 2011. Impacts of biochar addition on methane and carbon dioxide emissions during composting of cattle manure, in Asia Pacific Biochar Conference Kyoto, 2011, 15-18 September 2011, Kyoto, Japan.

Sophal, C.; Khang, D. N.; Preston, T.; Leng, R. 2013. Nitrate replacing urea as a fermentable $\mathrm{N}$ source decreases enteric methane production and increases the efficiency of feed utilization in Yellow cattle, Livestock Research for Rural Development 25(7) [online], [cited 28 December 2016]. Available from Internet: http://www.lrrd.org/lrrd25/7/soph25113.htm

Spokas, K. A. 2013. Impact of biochar field aging on laboratory greenhouse gas production potentials, Global Change Biology Bioenergy 5(2): 165-176.

https://doi.org/10.1111/gcbb.12005
Spokas, K. A.; Koskinen, W. C.; Baker, J. M.; Reicosky, D. C. 2009. Impacts of woodchip biochar additions on greenhouse gas production and sorption/degradation of two herbicides in a Minnesota soil, Chemosphere 77(4): 574-581. https://doi.org/10.1016/j.chemosphere.2009.06.053

Spokas, K. A.; Reicoscoky, D. A. 2009. Impacts of sixteen different biochars on soil greenhouse gas production, Annals of Environmental Science 3(4): 179-193.

Steiner, C.; Das, K. C.; Melear, N.; Lakly, D. 2010. Reducing nitrogen loss during poultry litter composting using biochar, Journal of Environmental Quality 39(4): 1236-1242. https://doi.org/10.2134/jeq2009.0337

Steiner, C.; Melear, N.; Harris, K.; Das, K. C. 2011. Biochar as bulking agent for poultry litter composting, Carbon Management 2(3): 227-230. https://doi.org/10.4155/cmt.11.15

Steudler, P.; Bowden, R.; Melillo, J.; Aber, J. 1989. Influence of nitrogen fertilization on methane uptake in temperate forest soils, Nature 341: 314-316. https://doi.org/10.1038/341314a0

Stieglmeier, M.; Mooshammer, M.; Kitzler, B.; Wanek, W.; Zechmeister-Boltenstern, S.; Richter, A. Schleper, C. 2014. Aerobic nitrous oxide production through $\mathrm{N}$-nitrosating hybrid formation in ammonia-oxidizing archaea, ISME Journal 8(5): 1135-1146. https://doi.org/10.1038/ismej.2013.220

Subedi, R.; Kammann, C.; Pelissetti, S.; Taupe, N.; Bertora, C.; Monaco, S.; Grignani, C. 2015. Does soil amended with biochar and hydrochar reduce ammonia emissions following the application of pig slurry?, European Journal of Soil Science 66(6): 1044-1053. https://doi.org/10.1111/ejss.12302

Subedi, R.; Taupe, N.; Pelissetti, S.; Petruzzelli, L.; Bertora, C.; Leahy, J. J.; Grignani, C. 2016. Greenhouse gas emissions and soil properties following amendment with manure-derived biochars: Influence of pyrolysis temperature and feedstock type, Journal of Environmental Management 166: 73-83. https://doi.org/10.1016/j.jenvman.2015.10.007

Suddick, E. C.; Six, J. 2013. An estimation of annual nitrous oxide emissions and soil quality following the amendment of high temperature walnut shell biochar and compost to a small scale vegetable crop rotation, Science of the Total Environment 465: 298-307. https://doi.org/10.1016/j.scitotenv.2013.01.094

Sutka, R. L.; Ostrom, N. E.; Ostrom, P. H.; Breznak, J. A.; Gandhi, H.; Pitt, A. J.; Li, F. 2006. Distinguishing nitrous oxide production from nitrification and denitrification on the basis of isotopomer abundances, Applied and Environmental Microbiology 72(1): 638-644. https://doi.org/10.1128/AEM.72.1.638-644.2006

Taghizadeh-Toosi, A.; Clough, T.; Sherlock, R.; Condron, L. 2012. Biochar adsorbed ammonia is bioavailable, Plant and Soil 350(1-2): 57-69.

https://doi.org/10.1007/s11104-011-0870-3

Taghizadeh-Toosi, A.; Clough, T. J.; Condron, L. M. Sherlock, R. R.; Anderson, C. R.; Craigie, R. A. 2011. Biochar incorporation into pasture soil suppresses in situ nitrous oxide emissions from ruminant urine patches, Journal of Environmental Quality 40(2): 468-476. https://doi.org/10.2134/jeq2010.0419

Terazawa, K.; Ishizuka, S.; Sakata, T.; Yamada, K.; Takahashi, M. 2007. Methane emissions from stems of Fraxinus mandshurica var. japonica trees in a floodplain forest, Soil Biology and Biochemistry 39(10): 2689-2692. https://doi.org/10.1016/j.soilbio.2007.05.013

Thomazini, A.; Spokas, K.; Hall, K.; Ippolito, J.; Lentz, R.; Novak, J. 2015. GHG impacts of biochar: Predictability for the 
same biochar, Agriculture, Ecosystems \& Environment 207: 183-191. https://doi.org/10.1016/j.agee.2015.04.012

Toth, J. D.; Dou, Z. 2016. Use and impact of biochar and charcoal in animal production systems, in M. Guo, Z. He, S. M. Uchimiya. (Eds.). Agricultural and environmental applications of biochar: advances and barriers. Madison, WI: Soil Science Society of America, Inc.

https://doi.org/10.2136/sssaspecpub63.2014.0043.5

Totusek, R.; Beeson, W. 1953. The nutritive value of wood charcoal for pigs, Journal of Animal Science 12(2): 271-281. https://doi.org/10.2527/jas1953.122271x

Troy, S. M.; Lawlor, P. G.; O’ Flynn, C. J.; Healy, M. G. 2013. Impact of biochar addition to soil on greenhouse gas emissions following pig manure application, Soil Biology and Biochemistry 60: 173-181. https://doi.org/10.1016/j.soilbio.2013.01.019

Turetsky, M. R.; Kotowska, A.; Bubier, J.; Dise, N. B.; Crill, P.; Hornibrook, E. R.; Minkkinen, K.; Moore, T. R.; MyersSmith, I. H.; Nykänen, H. 2014. A synthesis of methane emissions from 71 northern, temperate, and subtropical wetlands, Global Change Biology 20(7): 2183-2197. https://doi.org/10.1111/gcb.12580

Turner, P. A.; Griffis, T. J.; Lee, X.; Baker, J. M.; Venterea, R. T.; Wood, J. D. 2015. Indirect nitrous oxide emissions from streams within the US Corn Belt scale with stream order, Proceedings of the National Academy of Sciences 112(32): 9839-9843. https://doi.org/10.1073/pnas.1503598112

Van Der Zee, F. P.; Cervantes, F. J. 2009. Impact and application of electron shuttles on the redox (bio) transformation of contaminants: a review, Biotechnology Advances 27(3): 256-277. https://doi.org/10.1016/j.biotechadv.2009.01.004

Van Groenigen, K. J.; Osenberg, C. W.; Hungate, B. A. 2011. Increased soil emissions of potent greenhouse gases under increased atmospheric $\mathrm{CO}_{2}$, Nature 475(7355): 214-216. https://doi.org/10.1038/nature10176

Van Zwieten, L.; Kammann, C. I.; Cayuela, M. L.; Singh, B. P.; Joseph, S.; Kimber, S.; Donne, S.; Clough, T. J.; Spokas, K. 2015. Biochar effects on nitrous oxide and methane emissions from soil, in J. Lehmann, S. Joseph (Eds.). Biochar for environmental management - science, technology and implementation. 2 ed. New York: Routledge.

Van Zwieten, L.; Singh, B.; Joseph, S. D.; Kimber, S.; Cowie, A.; Chan, K. Y. 2009. Biochar and the emissions of non- $\mathrm{CO}_{2}$ greenhouse gases from soil, in J. Lehmann, S. Joseph (Eds.). Biochar for environmental management, science and technology. London: Earthscan.

Vandecasteele, B.; Sinicco, T.; D’hose, T.; Vanden Nest, T.; Mondini, C. 2016. Biochar amendment before or after composting affects compost quality and $\mathrm{N}$ losses, but not $\mathrm{P}$ plant uptake, Journal of Environmental Management 168: 200-209. https://doi.org/10.1016/j.jenvman.2015.11.045

Volkmann, A. 1935. Behandlungsversuche der Kaninchen-bzw. Katzencoccidiose mit Viscojod und Carbo medicinalis "Merck": Doctoral Thesis. University of Leipzig.

Vongsamphanh, P.; Napasirth, V.; Inthapanya, S.; Preston, T. 2015. Effect of biochar and leaves from sweet or bitter cassava on gas and methane production in an in vitro rumen incubation using cassava root pulp as source of energy, Livestock Research for Rural Development 27(04) [online], [cited 28 December 2016]. Available from Internet: http://www.lrrd. org/lrrd27/4/phan27072.html
Walter, K. M.; Zimov, S. A.; Chanton, J. P.; Verbyla, D.; Chapin, F. S. 2006. Methane bubbling from Siberian thaw lakes as a positive feedback to climate warming, Nature 443(7107): 71-75. https://doi.org/10.1038/nature05040

Wang, Z.; Zheng, H.; Luo, Y.; Deng, X.; Herbert, S.; Xing, B. 2013a. Characterization and influence of biochars on nitrous oxide emission from agricultural soil, Environmental Pollution 174: 289-296. https://doi.org/10.1016/j.envpol.2012.12.003

Wang, C.; Lu, H.; Dong, D.; Deng, H.; Strong, P. J.; Wang, H.; $\mathrm{Wu}, \mathrm{W} .2013 \mathrm{~b}$. Insight into the effects of biochar on manure composting: evidence supporting the relationship between $\mathrm{N}_{2} \mathrm{O}$ emission and denitrifying community, Environmental Science \& Technology 47(13): 7341-7349.

https://doi.org/10.1021/es305293h

Wang, Y.; Xue, M.; Zheng, X.; Ji, B.; Du, R.; Wang, Y. 2005. Effects of environmental factors on $\mathrm{N}_{2} \mathrm{O}$ emission from and $\mathrm{CH}_{4}$ uptake by the typical grasslands in the Inner Mongolia, Chemosphere 58(2): 205-215.

https://doi.org/10.1016/j.chemosphere.2004.04.043

Ward, B. J.; Yacob, T. W.; Montoya, L. D. 2014. Evaluation of solid fuel char briquettes from human waste, Environmental Science and Technology 48(16): 9852-9858. https://doi.org/10.1021/es500197h

Wells, N. S.; Baggs, E. M. 2014. Char amendments impact soil nitrous oxide production during ammonia oxidation, Soil Science Society of America Journal 78(5): 1656-1660. https://doi.org/10.2136/sssaj2013.11.0468n

Whalen, S. C. 2005. Biogeochemistry of methane exchange between natural wetlands and the atmosphere, Environmental Engineering Science 22(1): 73-94. https://doi.org/10.1089/ees.2005.22.73

Wollenberg, E.; Richards, M.; Smith, P.; Havlík, P.; Obersteiner, M.; Tubiello, F. N.; Herold, M.; Gerber, P.; Carter, S.; Reisinger, A.; Van Vuuren, D. P.; Dickie, A.; Neufeldt, H.; Sander, B. O.; Wassmann, R.; Sommer, R.; Amonette, J. E.; Falcucci, A.; Herrero, M.; Opio, C.; Roman-Cuesta, R. M.; Stehfest, E.; Westhoek, H.; Ortiz-Monasterio, I.; Sapkota, T.; Rufino, M. C.; Thornton, P. K.; Verchot, L.; West, P. C.; Soussana, J.-F.; Baedeker, T. Sadler, M.; Vermeulen, S.; Campbell, B. M. 2016. Reducing emissions from agriculture to meet the $2{ }^{\circ} \mathrm{C}$ target, Global Change Biology 22(12): 38593864. https://doi.org/10.1111/gcb.13340

Wrage, N.; Velthof, G. L.; Van Beusichem, M. L. Oenema, O. 2001. Role of nitrifier denitrification in the production of nitrous oxide, Soil Biology and Biochemistry 33(12-13): 17231732. https://doi.org/10.1016/S0038-0717(01)00096-7

Xie, Z.; Xu, Y.; Liu, G.; Liu, Q.; Zhu, J.; Tu, C.; Amonette, J. E.; Cadisch, G.; Yong, J. W.; Hu, S. 2013. Impact of biochar application on nitrogen nutrition of rice, greenhouse-gas emissions and soil organic carbon dynamics in two paddy soils of China, Plant and Soil 370(1-2): 527-540. https://doi.org/10.1007/s11104-013-1636-x

Yanai, Y.; Toyota, K.; Okazaki, M. 2007. Effects of charcoal addition on $\mathrm{N}_{2} \mathrm{O}$ emissions from soil resulting from rewetting airdried soil in short-term laboratory experiments, Soil Science and Plant Nutrition 53(2): 181-188. https://doi.org/10.1111/j.1747-0765.2007.00123.x

Yoo, G.; Kang, H. 2012. Effects of biochar addition on greenhouse gas emissions and microbial responses in a short-term laboratory experiment, Journal of Environmental Quality 41(4): 1193-1202. https://doi.org/10.2134/jeq2011.0157 
Yu, L.; Yuan, Y.; Tang, J.; Wang, Y.; Zhou, S. 2015. Biochar as an electron shuttle for reductive dechlorination of pentachlorophenol by Geobacter sulfurreducens, Scientific Reports 5(16221). https://doi.org/10.1038/srep16221

Yu, L. Q.; Tang, J.; Zhang, R. D.; Wu, Q. H.; Gong, M. M. 2013. Effects of biochar application on soil methane emission at different soil moisture levels, Biology and Fertility of Soils 49(2): 119-128. https://doi.org/10.1007/s00374-012-0703-4

Zhang, A.; Bian, R.; Pan, G.; Cui, L.; Hussain, Q.; Li, L.; Zheng, J.; Zheng, J.; Zhang, X.; Han, X.; Yu, X. 2012. Effects of biochar amendment on soil quality, crop yield and greenhouse gas emission in a Chinese rice paddy: a field study of 2 consecutive rice growing cycles, Field Crops Research 127: 153-160. https://doi.org/10.1016/j.fcr.2011.11.020

Zhang, A.; Cui, L.; Pan, G.; Li, L.; Hussain, Q.; Zhang, X.; Zheng, J.; Crowley, D. 2010. Effect of biochar amendment on yield and methane and nitrous oxide emissions from a rice paddy from Tai Lake plain, China, Agriculture, Ecosystems \& Environment 139(4): 469-475. https://doi.org/10.1016/j. agee.2010.09.003

Zumft, W. G. 1997. Cell biology and molecular basis of denitrification, Microbiology and Molecular Biology Reviews 61(4): 533-616.

Claudia KAMMANN. PhD, Professor for Climate Change Research for Special Crops, Institute for Soil Science and Plant Nutrition, Hochschule Geisenheim University, Geisenheim, Germany, 58 peer-reviewed articles in scientific journals, 7 book chapters, 2453 citations, h-index 27 (Google Scholar).

Jim IPPOLITO. PhD, Associate Professor in the Department of Soil and Crop Sciences, Colorado State University, Fort Collins, CO, USA. 170 publications in peer reviewed scientific publications, book chapters, conference reports, and experiment station technical reports and bulletins. 2099 citations, h-index 24 (Google Scholar).

Nikolas HAGEMANN. PhD, Nikolas Hagemann, PhD. Researcher at University of Tuebingen, Germany. 2 peer-reviewed articles, 5 book chapters, 16 citations, h-index 3 (Google Scholar).

Nils BORCHARD. PhD, Soil Science Expert at the Center for International Forestry Research (CIFOR), Jalan CIFOR, 16115 Bogor Barat, Indonesia and at the Deprtament of Soil Science and Soil Ecology, Institute of Geography, RuhrUniversity of Bochum, Universitätsstr. 150, 44801 Bochum, Germany. 15 peer reviewed publications, 3 non-peer reviewed publication, 156 citations, h-index 7 (WoS).

Maria Luz CAYUELA. PhD, is a researcher at the National Research Council in Spain. She has published 40 articles in peer- reviewed journals and 6 book chapters. 2046 citations, h-index 24. (Google Scholar)

José M. ESTAVILLO. PhD, Professor of Plant Physiology, Faculty of Science and Technology, University of the Basque Country/EHU, Spain, 40 peer-reviewed articles in scientific journals, 783 citations, h-index 15 (WoS).

Teresa FUERTES-MENDIZABAL. PhD, Researcher, Faculty of Science and Technology, University of the Basque Country/EHU, Spain, 9 peer-reviewed articles in scientific journals, 71 citations, h-index 5 (WoS).

Simon JEFFERY. PhD, Senior Lecturer in Sustainable Technology. Crop and Environment Sciences Department, Harper Adams University, Newport, Shropshire, TF10 8NB. United Kingdom. 24 peer reviewed articles in scientific journals, 3 policy reports to the European Commission. Editor of two atlases (including lead editor of one), 3 book chapters. 1768 citations, h-index 15 (Google Scholar).

Jürgen KERN. PhD, Senior Scientist of Biogeochemistry, Leibniz Institute for Agricultural Engineering Potsdam-Bornim, Germany, 1211 citations, h-index 16 (Google Scholar).

Jeff NOVAK. PhD, Research Soil Scientist, in the United States Department of Agriculture, Agriculture Research ServiceCoastal Plains Research Center, Florence, South Carolina, USA. 150 publications in peer reviewed scientific publications, book chapters, and conference reports. 4130 citations; h-index 26 (Scopus).

Daniel RASSE. PhD, Senior Scientist and Head of the Department for Soil Quality and Climate Change at the Norwegian Institute of Bioeconomy Research, Aas, Norway, 55 peer-reviewed articles in scientific journals, 2948 citations, h-index 25 (Scopus).

Sanna SAARNIO. PhD, Lecturer in the Department of Environmental and Biological Sciences, University of Eastern Finland, Finland, 52 peer-reviewed articles in scientific journals or books, 1400 citations, h-index 20 (WoS). 
Hans-Peter SCHMIDT. Director of Ithaka Institute for Carbon Strategies, Arbaz, Switzerland, 16 peer-reviewed articles, 9 book chapters, 259 citations, h-index 9 (google scholar).

Kurt SPOKAS. PhD, Research Soil Scientist with the United States Department of Agriculture-Agricultural Research Service, Soil and Water Management Laboratory, 1991 Upper Buford Circle, St. Paul, MN 55108. He has produced over 200 scientific publications in peer reviewed journals, book chapters, conference proceedings, and bulletins. 4904 citations; h-index 31 (google scholar).

Nicole WRAGE-MÖNNIG. PhD, Professor of Grassland and Forage Sciences, Faculty of Agricultural and Environmental Sciences, University of Rostock, Germany, 45 peer-reviewed articles in scientific journals, 6 monographs and book chapters, 1968 citations, h-index 18 (WoS). 